\title{
Sulodexide - unrealized potential in dermatology
}

\section{Sulodeksyd - niewykorzystany potencjał w dermatologii}

\author{
Dorota Krasowska, Beata Polkowska-Pruszyńska, Anna Michalak-Stoma
}

Department of Dermatology, Venereology, and Paediatric Dermatology, Medical University of Lublin, Poland

Katedra i Klinika Dermatologii, Wenerologii i Dermatologii Dziecięcej Uniwersytetu Medycznego w Lublinie, Polska

Dermatol Rev/Przegl Dermatol 2019, 106, 52-70

DOI: https://doi.org//0.5 | 14/dr.2019.83444

\author{
CORRESPONDING AUTHOR/ \\ ADRES DO KORESPONDENCJI: \\ Beata Polkowska-Pruszyńska \\ Katedra i Klinika \\ Dermatologii, Wenerologii \\ i Dermatologii Dziecięcej \\ Uniwersytet Medyczny \\ w Lublinie \\ ul. Staszica 16 \\ 20-080 Lublin \\ e-mail: polkowska.beata@gmail. \\ com
}

\begin{abstract}
Sulodexide is a highly purified mixture of glycosaminoglycans composed of fast mobility heparin $(80 \%)$ and dermatan sulfate $(20 \%)$. Glycosaminoglycans constitute a group of heteropolysaccharides consisting of repeating disaccharide units, which contain amino sugar combined with uronic acid or a hexose. Glycosaminoglycans build glycocalyx covering endothelium of blood vessels, and thus, play an important role in vascular homeostasis. Multi-directional activity of sulodexide including antithrombotic, fibrinolytic, anti-aggregation, anti-inflammatory, anti-proliferative, and anti-oxidative qualities, as well as a high safety profile have allowed using the drug in numerous entities. Advantageous results of sulodexide therapy are observed in diseases involving endothelial damage, prothrombotic or inflammatory states. Thanks to its pleiotropic effects, sulodexide can be also applied in treatment of skin diseases.
\end{abstract}

\section{STRESZCZENIE}

Sulodeksyd to wysoce oczyszczona mieszanina glikozaminoglikanów złożona w $80 \%$ z heparyny szybko przemieszczającej się w polu elektroforezy oraz w $20 \%$ z siarczanu dermatanu. Glikozaminoglikany są grupą heteropolisacharydów składających się z powtarzających się jednostek disacharydowych, zawierających aminocukier połączony z kwasem uronowym lub heksozą. Glikozaminoglikany stanowią budulec glikokaliksu pokrywającego śródbłonek naczyń krwionośnych i odgrywają istotną rolę w homeostazie naczyniowej. Wielokierunkowe działanie sulodeksydu obejmujące właściwości przeciwzakrzepowe, fibrynolityczne, antyagregacyjne, przeciwzapalne, antyproliferacyjne i antyoksydacyjne oraz wysoki profil bezpieczeństwa umożliwiły zastosowanie leku w wielu jednostkach chorobowych. Korzystne efekty terapii sulodeksydem obserwuje się $\mathrm{w}$ chorobach przebiegających z uszkodzeniem śródbłonka, ze stanami prozakrzepowymi i zapalnymi. Dzięki właściwościom plejotropowym sulodeksyd znalazł również zastosowanie w terapii chorób skóry.

Key words: sulodexide, therapy, skin diseases.

Słowa kluczowe: sulodeksyd, terapia, choroby skóry. 


\section{INTRODUCTION}

Sulodexide is an antithrombotic heparinoid that is commonly used in treatment of cardio-vascular diseases. A highly purified mixture of glycosaminoglycans composed of fast mobility heparin $(80 \% \mathrm{FMH})$ and dermatan sulfate $(20 \% \mathrm{DeS})$, is extracted from porcine intestinal mucosa [1-3]. Low molecular weight of both sulodexide fractions allows for intravenous and oral drug administration. Beneficial effects of the drug were noticed in a patient group, in which heparin had been used and heparin-induced thrombocytopenia type I/II (HIT I/II) developed - it was not observed in a group treated with sulodexide [1].

\section{CHEMICAL STRUCTURE}

Glycosaminoglycans constitute a group of unbranched negatively-charged polysaccharides composed of disaccharide units. Due to the presence of sulfate groups there can be sulfated (DeS, FMH) and non-sulfated glycosaminoglycans [4]. FMH is a low molecular mass fraction (7 kDa) and shows a lower antithrombotic activity as well as sulfonation level as compared with unfractioned heparin (UFH) [1, 5]. Similarly to UFH, FMH is composed of repeating disaccharide units containing amino sugar bonded by a $\beta$-glycoside linkage in position 1,4- to amino sugar (N-acetylglucosamine or $\alpha-\mathrm{N}$-sulphate-glucosamine) and uronic acid ( $\alpha$-L-iduronic acid or $\beta$-D-glucuronic acid). Within the group of sulfated glycosaminoglycans a dominating disaccharide unit is composed of $\mathrm{N}$-acetyl-4-sulfate linked to $\beta$-D-galactosamine in -3 position and $\alpha$-L-iduronic acid in position $-1,4$. Sulfate groups in galactosamine may be exchanged or also found in -6 position; whereas L-iduronic acid may be found in 2 position $[1,6,7]$. Molecular mass of dermatan sulfate is $15-40 \mathrm{kDa}[1,4]$.

\section{PHARMACOKINETICS}

Sulodexide is available in intravenous or intramuscular forms as ampoules containing 600 lipasemic units (LSU) equalling $60 \mathrm{mg}$ of an active ingredient, and in an oral form containing 250 LSU equalling $25 \mathrm{mg}$ of an active ingredient. Maximal plasma concentration of sulodexide amounting to $8-20 \mathrm{mg} / 1$ is observed directly after IV administration of 50-100 $\mathrm{mg}$ of the drug. The level gradually decreases within 1-4 hours down to $0.5-1 \mathrm{mg} / \mathrm{l}$, and after 18 hours the drug is undetectable in serum. With oral administration, the drug is absorbed after about 1-2 hours, and its maximal serum concentration is observed after 4 hours counting from its administration [4]. Bioavailability of the drug is comparable with intravenous

\section{WPROWADZENIE}

Sulodeksyd to heparynoid o działaniu przeciwzakrzepowym powszechnie stosowany w terapii chorób sercowo-naczyniowych. Wysoce oczyszczona mieszanina glikozaminoglikanów złożona w 80\% z heparyny szybko przemieszczającej się w polu elektroforezy (fast mobility heparin - FMH) oraz w 20\% z siarczanu dermatanu (dermatan sulfate - DeS) [1-3] pozyskiwana jest poprzez ekstrakcję błony śluzowej jelit świńskich. Mała masa cząsteczkowa obu frakcji sulodeksydu umożliwia podaż zarówno dożylną, jak i doustną. Korzyści ze stosowania leku dostrzeżono u chorych, u których stosowano heparynę i doszło do rozwoju małopłytkowości (heparin-induced thrombocytopenia type I/II - HIT I/II), niestwierdzanej u chorych leczonych sulodeksydem [1].

\section{BUDOWA CHEMICZNA}

Glikozaminoglikany stanowią grupę nierozgałęzionych, ujemnie naładowanych polisacharydów złożonych z jednostek disacharydowych. Ze względu na obecność grup siarczanowych wyróżnia się glikozaminoglikany sulfonowane (m.in. DeS, FMH) oraz niesulfonowane [4]. FMH jest frakcją o małej masie cząsteczkowej (7 kDa) oraz niższej aktywności przeciwzakrzepowej i stopniu sulfonowania w porównaniu z heparyną niefrakcjonowaną (unfractioned heparin - UFH) [1, 5]. Podobnie jak UFH, FMH złożona jest z powtarzających się jednostek disacharydowych, zawierających aminocukier połączony wiązaniem $\beta$-glikozydowym w pozycji 1,4- z aminocukrem (N-acetyloglukozaminą lub $\alpha$-N-siarczano-glukozaminą) oraz kwasem uronowym (kwasem $\alpha$-L-iduronowym lub $\beta$-D-glukuronowym). W grupie sulfonowanych glikozaminoglikanów dominująca jednostka disacharydowa złożona jest $\mathrm{z}$ N-acetylano-4-siarczanu połączonego z $\beta$-D-galaktozaminą w pozycji -3 i kwasem $\alpha$-L-iduronowym w pozycji $-1,4$. Grupy siarczanowe w galaktozaminie mogą być zamiennie lub dodatkowo położone w pozycji -6, a kwas L-iduronowy w pozycji 2 $[1,6,7]$. Masa cząsteczkowa siarczanu dermatanu wynosi $15-40 \mathrm{kDa}[1,4]$.

\section{FARMAKOKINETYKA}

Sulodeksyd jest dostępny w formie dożylnej bądź domięśniowej w postaci ampułek zawierających 600 jednostek lipemicznych (lipasemic units - LSU) odpowiadających $60 \mathrm{mg}$ substancji czynnej oraz w formie doustnej zawierającej 250 LSU odpowiadających $25 \mathrm{mg}$ substancji czynnej. Maksymalne stężenie sulodeksydu w osoczu wynoszące 8-20 mg/l obserwuje się bezpośrednio po dożylnym podaniu 50-100 mg leku. Stężenie to stopniowo się zmniejsza w czasie 
and oral forms. Antithrombotic activity is achieved after 1-2 hours in case of IV administration, and 5-7 hours with oral administration. After IV administration, FMH half-life is shorter than DeS, whereas with oral administration half-life of both components of sulodexide is comparable [1]. Due to a higher affinity to surface of vascular endothelium than to plasma proteins and a large distribution area, anti-coagulation effect in visible in global laboratory markers of homeostasis observed only directly after IV drug administration. Minimal anticoagulation activity of oral sulodexide is perceivable on the basis of parameters such as concentration of prothrombin fragments $1+2$ $(\mathrm{F} 1+2)$ and thrombin-antithrombin (TAT) complex. Hepatic metabolism of sulodexide is based to a large extent on desulfonation. The drug is excreted from the system by kidneys (55\%) and bile $(23 \%)[1,4,8]$.

\section{MECHANISM}

Antithrombotic potential of sulodexide stems from interaction of FMH and dermatan sulfate with serine protease inhibitors present in human body - with antithrombin III and heparin cofactor II accordingly. As a result of this interaction, thrombin and its precursor, prothrombin, are directly inhibited, what in turn leads to extension of coagulation time, prothrombin time (PT) as well as activated partial thromboplastin time (APTT), and a delay in blood clot formation. Sulodexide, right after heparin, is the second glycosaminoglycan that inhibits factor Xa in the most potent way [1]. Thanks to anticoagulation qualities, sulodexide may be used in disease involving prothrombotic conditions, including arterial and venous thrombosis, ulcerations on lowers legs secondary to chronic venous insufficiency, postphlebitic syndrome, or intermittent claudication associated with peripheral artery occlusive disease. Due to anti-atherosclerotic potential of sulodexide, its application in arterial thrombosis is all the more justified. Sulodexide lowers cholesterol concentration and aids the release of lipoprotein lipase. Apart from anti-coagulation activity, it is also characterized by an ability to amplify plasma fibrinolytic activity. Sulodexide lowers the level of plasminogen activator inhibitor-1 (PAI-1) and D-dimers; similarly to heparin, it also inhibits cathepsin $\mathrm{G}$ activity and prevents blood platelet activation and aggregation $[1,9]$.

Glycosaminoglycans were demonstrated to play a protective role in preventing reperfusion injuries in ischaemic heart muscle by modulating activation of a complement cascade, among others. Lauver et al. assessed experimentally a cardioprotective activity of sulodexide. After a 30-minut long regional occlusion of a coronary artery, New Zealand rabbits were administered IV doses of sulodexide. It was assessed that drug administration considerably decreased extent
1-4 godzin do 0,5-1 mg/l, a po 18 godzinach lek w surowicy jest niewykrywalny. Przy doustnym podaniu lek ulega wchłonięciu po około 1-2 godzinach, a jego maksymalne stężenie w surowicy stwierdza się po 4 godzinach od podania [4]. Biodostępność leku jest porównywalna dla formy dożylnej i doustnej. Działanie przeciwzakrzepowe osiągane jest po 1-2 godzinach od podania dożylnego i 5-7 godzinach od aplikacji doustnej. Po dożylnym podaniu leku okres półtrwania FMH jest krótszy niż DeS, natomiast przy podaniu doustnym okres półtrwania obu składników sulodeksydu jest porównywalny [1]. Ze względu na większe powinowactwo do powierzchni śródbłonka naczyniowego niż białek osocza i duży obszar dystrybucji działanie antykoagulacyjne dostrzegalne w ogólnych wykładnikach laboratoryjnych homeostazy obserwuje się jedynie bezpośrednio po dożylnym podaniu leku. Minimalne działanie antykoagulacyjne doustnej formy sulodeksydu można dostrzec dzięki takim parametrom, jak stężenie fragmentów protrombiny $1+2(\mathrm{~F} 1+2)$ oraz kompleksów trombina-antytrombina (TAT). Metabolizm wątrobowy sulodeksydu opiera się głównie na desulfonacji. Lek wydalany jest z organizmu w $55 \%$ przez nerki i w 23\% z żółcią $[1,4,8]$.

\section{MECHANIZM DZIAŁANIA}

Przeciwzakrzepowy potencjał sulodeksydu wynika z interakcji FMH i siarczanu dermatanu z obecnymi w organizmie człowieka inhibitorami proteazy serynowej - odpowiednio z antytrombiną III i kofaktorem heparyny II. W wyniku tej interakcji dochodzi do bezpośredniego zahamowania trombiny oraz jej prekursora - protrombiny, czego efektem jest wydłużenie czasu krzepnięcia, czasu protrombinowego (prothrombin time - PT) oraz czasu częściowej tromboplastyny po aktywacji (activated partial thromboplastin time - APTT), a także opóźnienie tworzenia się skrzepu. Sulodeksyd, po heparynie, jest drugim glikozaminoglikanem najsilniej hamującym czynnik Xa [1]. Antykoagulacyjne właściwości sulodeksydu umożliwiły jego zastosowanie w chorobach przebiegających ze stanami prozakrzepowymi, m.in. w zakrzepicy tętniczej i żylnej, owrzodzeniach podudzi na tle przewlekłej niewydolności żylnej, zespole pozakrzepowym i w chromaniu przestankowym związanym z niedrożnością tętnic obwodowych. Ze względu na potencjał przeciwmiażdżycowy sulodeksydu jego zastosowanie w zakrzepicy tętniczej jest tym bardziej uzasadnione. Sulodeksyd zmniejsza stężenie cholesterolu i sprzyja uwalnianiu lipazy lipoproteinowej. Poza działaniem przeciwzakrzepowym cechuje się również zdolnością do wzmagania fibrynolitycznej aktywności osocza. Sulodeksyd obniża poziom inhibitora aktywatora plazminogenu typu 1 
of myocardial infarction as well as serum troponin I concentration during reperfusion, what maintained the hypothesis that sulodexide may be a successful supplement in revascularisation of a heart muscle [10].

Anti-coagulation treatment plays an important role in preventing cardio-vascular incidents and death after acute myocardial infarction. Compounds containing glycosaminoglycans, including sulodexide, are characterized by a pro-fibrinolytic and anti-coagulation profile, and thus, can be applied in this group of patients. A long-term sulodexide therapy used in prevention of death and thromboembolic incidents in patients with history of acute myocardial infarction, which was assessed by Italian researchers, was associated with a reduction of total mortality rate, and a decrease in risk of subsequent infarction and left ventricular thrombus [11].

Intravenous sulodexide administration results in a decrease in concentration of pro-inflammatory cytokines, including interleukin (IL)-1 $\beta$, IL-6, IL-8, monocyte chemoattractant protein-1 (MCP-1), and vascular endothelial growth factor (VEGF) [9, 12, 13]. Furthermore, an increase in concentration of anti-inflammatory hepatocyte growth factor (HGF) can be observed [13]. Sulodexide is also an inhibitor of matrix metalloproteinases (MMP), including MMP-9 responsible for degradation of endothelial cell matrixes $[4,14]$. Sulodexide's protective role with regard to the endothelium allows for using it in diseases involving endothelial damage, including chronic venous insufficiency. An ability to bind with endothelial cells has a beneficial influence on the structure, integrity, and function of glycocalyx. Sulodexide reduces effects of pathological processes within the endothelium that are associated with ischaemia and reperfusion, hypoxia or hyperglycaemia [2]. Hyperglycaemia secondary to diabetic nephropathy leads to oxidative stress in vascular endothelial cells of glomeruli, in which hypertrophy of basal membrane and attenuation of glycosaminoglycan layer are also observed. Application of sulodexide exerts a beneficial influence on improving a glycocalyx function, and reduces release of free radicals and pro-inflammatory cytokines, while exhibiting renoprotective activities at early stages of diabetic nephropathy $[15,16]$. Sulodexide therapy is also associated with a significant reduction of proteinuria [15].

\section{CLINICAL USAGE}

\section{Peripheral vessel diseases (chronic venous disease/peripheral arterial disease)}

Chronic venous disease (CVD) is a condition with a complex etiopathogenesis including nume- (plasminogen activator inhibitor-1 - PAI-1) i D-dimerów oraz $\mathrm{w}$ porównywalnym stopniu $\mathrm{z}$ heparyną hamuje aktywność katepsyny G i zapobiega aktywacji oraz agregacji płytek krwi [1,9].

Wykazano ochronną rolę glikozaminoglikanów w zapobieganiu uszkodzeniom reperfuzyjnym w niedokrwionym mięśniu sercowym, m.in. przez modulację aktywacji kaskady dopełniacza. Lauver i wsp. ocenili doświadczalnie kardioprotekcyjne działanie sulodeksydu. Pod koniec 30-minutowego regionalnego zamknięcia tętnicy wieńcowej królikom nowozelandzkim podawano dożylnie sulodeksyd. Oceniono, że podawanie leku znacznie zmniejszyło rozległość zawału mięśnia sercowego, a także stężenie troponiny I w surowicy podczas reperfuzji, podtrzymując hipotezę, że sulodeksyd może być skutecznym środkiem wspomagającym w rewaskularyzacji mięśnia sercowego [10].

Leczenie przeciwzakrzepowe odgrywa ważną rolę w zapobieganiu incydentom sercowo-naczyniowym i śmierci po przebyciu ostrego zawału mięśnia sercowego. Związki zawierające glikozaminoglikany, w tym sulodeksyd, charakteryzujące się profibrynolitycznym i przeciwzakrzepowym profilem działania znajdują zastosowanie $\mathrm{w}$ tej grupie chorych. Długoterminowa terapia sulodeksydem w zapobieganiu zgonom i zdarzeniom zakrzepowo-zatorowym u chorych po przebytym ostrym zawale mięśnia sercowego oceniana przez włoskich badaczy wiązała się z redukcją całkowitej śmiertelności, zmniejszeniem ryzyka wystąpienia ponownego zawału i skrzepu w lewej komorze [11].

Pod wpływem dożylnego podania sulodeksydu zmniejsza się stężenie cytokin prozapalnych, takich jak interleukina (IL)-1 $\beta$, IL-6, IL-8, białko chemoatrakcyjne monocytów 1 (monocyte chemoattractant protein 1 - MCP-1) oraz czynnik wzrostu śródbłonka naczyniowego (vascular endothelial growth factor - VEGF) $[9,12$, 13]. Ponadto można zaobserwować wzrost stężenia czynnika wzrostu hepatocytów (hepatocyte growth factor - HGF) o działaniu przeciwzapalnym [13]. Sulodeksyd jest również inhibitorem metaloproteinaz (matrix metalloproteinases - MMP), w tym MMP-9 odpowiedzialnej za degradację macierzy komórek śródbłonka [4, 14]. Ochronna rola w stosunku do śródbłonka umożliwia zastosowanie sulodeksydu w chorobach przebiegających z jego uszkodzeniem, m.in. przewlekłej niewydolności żylnej. Zdolność do wiązania się z komórkami śródbłonka wpływa korzystnie na strukturę, integralność i funkcję glikokaliksu. Sulodeksyd redukuje skutki procesów patologicznych w obrębie śródbłonka związanych z niedokrwieniem i reperfuzją, hipoksją oraz hiperglikemią [2]. Hiperglikemia w przebiegu nefropatii cukrzycowej prowadzi do stresu oksydacyjnego w komórkach śródbłonka naczyń kłębuszków nerkowych, w których ponadto obserwuje się przerost błony podstawnej i ścieńczenie warstwy glikozaminoglika- 
rous morphological and functional changes in the venous system. Disorders are mainly observed in lower limbs. Frequency of CVD incidence amounts to $60-70 \%$, and in Poland CVD is observed in $47 \%$ of women and $37 \%$ of men $[4,17,18]$. Patients with genetic predispositions may develop telangiectasias, venulectasias, and varices when influenced by environmental factors. Patients with advanced CVD complain about pain, erythema, oedema, and eczema on the skin of lower limbs. Progression of the disease may lead to development of venous ulcers [17]. Venous hypertension is a key pathogenetic element in CVD development. At the core of this phenomenon is a venous reflux resulting from insufficiency of venous valves, in which structural disorders and histopathological lesions including abnormalities within collagen and vascular endothelium are observed. Moreover, intensified inflammation with monocyte and macrophage infiltration as well as an increase in expression of intercellular adhesion molecule-1 (ICAM-1) are observed within venous valves and walls [19]. A consequence of chronic venous hypertension is stasis in microcirculation, capillary insufficiency and endothelial damage. Within the course of microcirculation disorders there appears an increased permeability of capillary walls, what in turn leads to development of oedemas, leucocyte migration, and creation of perivascular inflammatory infiltration. Haemoglobin and hemosiderin, which are decomposition products of erythrocytes migrating to extravascular transudate, constitute a strong chemotactic factors $[4,20]$. Inflammation causes a cascade of changes involving activation of phospholipase $\mathrm{A}_{2}$ and arachidonic acid, leucocyte activation, an increase in expression of ICAM-1, pro-inflammatory cytokines, and growth factors. A dysfunctional relation between metalloproteinases and their tissue inhibitors results in degeneration of extracellular matrix and vascular remodelling [21]. The above processes lead to chronic inflammatory lesions in adjacent skin and subcutis, where eventually venous ulcers develop.

The CVD therapy should be complex and commence with modification in lifestyle as well as intensification of physical activities. The basis of the therapy is compression treatment that involves wearing bands and stockings, as well as usage of pneumatic compression massage. Pharmacological treatment constitutes a type of adjuvant therapy with regard to compression therapy. Chronic nature of the disease causes that patients require continual adjunctive therapy, even after surgical interventions [4]. The main aim of pharmacological treatment and usage of phlebotropic drugs is to decrease venous pressure by influencing endothelial function and intravascular homeostasis. Given this context, sulodexide plays an important role thanks to its mechanism. In a rando- nów. Zastosowanie sulodeksydu wpływa na poprawę funkcji glikokaliksu, redukuje uwalnianie wolnych rodników i cytokin prozapalnych, wykazując działanie renoprotekcyjne we wczesnym stadium nefropatii cukrzycowej $[15,16]$. Terapia sulodeksydem wiąże się również z istotną redukcją proteinurii [15].

\section{ZASTOSOWANIE KLINICZNE}

\section{Choroby naczyń obwodowych (przewlekła choroba żylna lub miażdżyca tętnic obwodowych)}

Przewlekła choroba żylna (chronic venous disease CVD) jest stanem o złożonej etiopatogenezie, obejmującym liczne zmiany morfologiczne i czynnościowe w układzie żylnym. Obserwowane zaburzenia dotyczą przede wszystkim kończyn dolnych. Częstość występowania CVD wynosi $60-70 \%$, a w populacji polskiej CVD obserwuje się u $47 \%$ kobiet i 37\% mężczyzn [4, 17, 18]. U osób predysponowanych genetycznie dochodzi do rozwoju teleengiektazji, żył siatkowatych i żylaków pod wpływem czynników środowiskowych. Chorzy w zaawansowanym stadium CVD skarżą się na ból, rumień, obrzęki i zmiany wypryskowe na skórze kończyn dolnych. Progresja choroby może prowadzić do powstania owrzodzeń żylnych [17]. Ważnym elementem patogenetycznym w rozwoju CVD jest nadciśnienie żylne. Istotą tego zjawiska jest refluks żylny wynikający z niewydolności zastawek żylnych, w obrębie których stwierdza się zaburzenia strukturalne oraz zmiany histopatologiczne obejmujące nieprawidłowości kolagenu i śródbłonka naczyniowego. Ponadto w obrębie zastawek i ścian żylnych obserwuje się nasilony stan zapalny z naciekiem z monocytów i makrofagów oraz wzrost ekspresji międzykomórkowej cząsteczki adhezyjnej (intercellular adhesion molecule-1 - ICAM-1) [19]. Skutkiem przewlekłego nadciśnienia żylnego jest zastój w mikrokrążeniu, niewydolność drobnych naczyń włosowatych i uszkodzenie śródbłonka. W przebiegu zaburzeń mikrokrążenia dochodzi do zwiększenia przepuszczalności ściany naczyń włosowatych, a także rozwoju obrzęków, migracji leukocytów i tworzenia się okołonaczyniowego nacieku zapalnego. Hemoglobina i hemosyderyna będące produktami rozpadu erytrocytów migrujących do przesięku zewnątrznaczyniowego stanowią silny czynnik chemotaktyczny [4, 20]. Stan zapalny powoduje kaskadę zmian obejmujących aktywację fosfolipazy $\mathrm{A}_{2}$ i kwasu arachidonowego, aktywacje leukocytów, zwiększenie ekspresji ICAM-1, cytokin prozapalnych i czynników wzrostu. Zaburzony stosunek metaloproteinaz do ich tkankowych inhibitorów skutkuje degradacją macierzy pozakomórkowej i przebudową naczyń [21]. Powyższe procesy prowa- 
mized study comparing a treatment group receiving 250 LSU of sulodexide daily for 45 days with a control group receiving placebo, it was stated that sulodexide decreases capillary permeability and improves blood flow parameters, as well as reduces symptoms such as pain, pruritus, oedema, or paraesthesia [22].

Coccheri et al. randomly assigned 235 patients with venous ulcers on lower legs that had been locally treated until that time to either a group receiving sulodexide or a group receiving placebo for 3 months. Sulodexide was administered intramuscularly in the dose of 600 LSU for 20 days, and then, orally twice a day in the dose of 500 LSU for 70 days. A percentage of patients, in whom complete recovery from ulcers was confirmed was higher in cases of sulodexide after 2 months and 3 months of observation. The same group of researchers observed also a beneficial effect of sulodexide therapy on a decrease of intensity of intermittent claudication secondary to atherosclerosis of lower limbs [23,24]. A beneficial influence of sulodexide in lower limb ulcers secondary to CVD was confirmed by subsequent groups of researches, including Kucharzewski et al. and Zou et al., which showed greater benefits of combination therapy with sulodexide as compared with isolated local treatment $[25,26]$. A meta-analysis assessing the influence of sulodexide on treatment of shank venous ulcers showed an increase in percentage of fully healed ulcers under the influence of sulodexide combination therapy with local treatment (including compression therapy) as compared with local treatment alone. A percentage of patients, whose ulcers were completely healed, amounted to $49.4 \%$ in the sulodexide group as compared with $29.8 \%$ in the group treated with isolated local treatment. In three studies included in the meta-analysis, patients were administered 600 LSU of intramuscular sulodexide for the first 20-30 days, and then, 250-500 LSU of oral sulodexide twice a day for 30-70 days. In one study, sulodexide was administered orally in the dose of 500 LSU daily [27].

In the study conducted by Boduła et al. that had assessed the influence of sulodexide and pentoxifylline on the course of obliterating peripheral arterial disease it was confirmed that sulodexide exerts an advantageous effect on the disease's symptoms. A significantly extended distance of intermittent claudication and reduction in pain were showed in the group of patients treated with sulodexide. Furthermore, it was confirmed that the distance of intermittent claudication in patients using sulodexide was prolonged to a greater extent as compared with pentoxifylline. As opposed to the study of Coccheri et al., a significant influence of preparations on parameters of arterial capacity determined in plethysmography was not shown [28]. A decrease in triglyceride and fibrinogen concentration, as well as an in increase in HDL dzą do przewlekłych zmian zapalnych w otaczającej skórze i tkance podskórnej, na podłożu których rozwijają się owrzodzenia żylne.

Terapia CVD powinna być kompleksowa i rozpoczynać się od modyfikacji stylu życia oraz zwiększenia aktywności fizycznej. Podstawą terapii jest leczenie kompresyjne obejmujące noszenie opasek i pończoch, a także stosowanie pneumatycznego masażu uciskowego. Leczenie farmakologiczne stanowi rodzaj terapii adiuwantowej w stosunku do kompresjoterapii. Przewlekły charakter schorzenia powoduje, że nawet po interwencji chirurgicznej pacjenci wymagają przewlekłej terapii wspomagającej [4]. Głównym celem leczenia farmakologicznego i stosowania środków flebotropowych jest obniżenie ciśnienia żylnego poprzez wpływ na funkcję śródbłonka i homeostazę wewnątrznaczyniową. Dlatego też istotną rolę odgrywa sulodeksyd ze względu na mechanizm działania. W badaniu $\mathrm{z}$ randomizacją porównującym grupę pacjentów otrzymujących 2 razy dziennie 250 LSU sulodeksydu przez 45 dni z grupą kontrolną przyjmującą placebo stwierdzono, że sulodeksyd zmniejsza przepuszczalność naczyń włosowatych i poprawia parametry przepływu krwi, a także redukuje takie objawy, jak ból, świąd, obrzęki i parestezje [22].

Coccheri i wsp. przydzielili losowo 235 pacjentów z owrzodzeniami żylnymi podudzi poddawanych dotychczas leczeniu miejscowemu do grupy otrzymującej sulodeksyd lub placebo przez 3 miesiące. Sulodeksyd był podawany domięśniowo w dawce 600 LSU przez 20 dni, a następnie doustnie 2 razy dziennie w dawce 500 LSU przez 70 dni. Odsetek pacjentów, u których stwierdzono pełne wygojenie owrzodzenia, był wyższy w przypadku stosowania sulodeksydu zarówno po 2 miesiącach, jak i 3 miesiącach obserwacji. Ta sama grupa badaczy obserwowała również wpływ terapii sulodeksydem na zmniejszenie nasilenia chromania przestankowego w przebiegu zarostowej miażdżycy tętnic kończyn dolnych [23, 24]. Pozytywny efekt stosowania sulodeksydu w terapii owrzodzeń kończyn dolnych na podłożu CVD potwierdziły badania kolejnych grup badaczy, m.in. Kucharzewskiego i wsp. oraz Zou i wsp., które wykazały większe korzyści ze stosowania terapii skojarzonej z sulodeksydem w porównaniu z izolowanym leczeniem miejscowym $[25,26]$. Metaanaliza oceniająca wpływ sulodeksydu na leczenie owrzodzeń żylnych podudzi wykazała wzrost odsetka owrzodzeń całkowicie wygojonych pod wpływem terapii skojarzonej sulodeksydem $\mathrm{z}$ leczeniem miejscowym (w tym kompresjoterapią) w porównaniu z samym leczeniem miejscowym. Odsetek chorych, u których osiągnięto pełne wygojenie owrzodzeń w grupie z zastosowaniem sulodeksydu, wynosił 49,4\% w porównaniu z 29,8\% w grupie chorych poddanych izolowanej terapii miejscowej. 
cholesterol were observed in patients with peripheral arterial disease that took sulodexide [29].

\section{Diabetic foot syndrome}

Diabetic foot syndrome constitutes a global medical social and economic problem [30]. Even 25\% of diabetic patients develop diabetic foot syndrome [31]. Especially elderly patients are prone to develop diabetic ulcers and may have their lower limbs amputated [32]. Diabetic ulcers develop first and foremost because of existing neuropathies and peripheral vessel diseases [30]. In order to lower the rates of incidence and mortality, it is necessary to diagnose diabetic foot syndrome early and use prophylaxis. Drugs improving rheological characteristics of blood, such as pentoxifylline, prostaglandin E1 or sulodexide, may be beneficial in treating disorders of peripheral circulation and regulating microcirculation that develop secondary to diabetic neuropathy [33]. Piaggesi et al. evaluated efficacy of sulodexide as a supplementary therapy in patients with critical limb ischemia secondary to diabetes that underwent percutaneous endovascular angioplasty. In the group of patients who took sulodexide improvements in microcirculation functions and reduction of pain were confirmed; however, there were no differences in ulcer healing and frequency of amputations as compared with the control group [34]. Jin et al. observed protective activity of sulodexide with regard to peripheral nerve damage caused by microvascular dysfunction in rats with induced diabetes [35]. In a study assessing the use of insulin in treating diabetic foot during monotherapy or a therapy with sulodexide, Koblik et al. did not observe changes in nerve conduction regardless of the therapy used. Yet, they confirmed a positive influence of sulodexide on cutaneous microcirculation in diabetic foot syndrome, while confirming an improvement in reactive skin blood flow and faster healing of ulcers [32].

Given the above within the course of diabetic microangiopathy, a potential adjunctive activity of sulodexide in a therapy of necrobiosis lipoidica should be mentioned. There exist reports regarding successful treatment of necrobiosis lipoidica-associated lesions with sulodexide administered daily in the dose of 500 LSU in combination with pentoxifylline and hyaluronic acid. A beneficial effect of combination therapy including sulodexide was confirmed, and 2/3 of ulcers were healed, whereas $1 / 3$ of lesions were shallowed [36].

\section{Metabolic syndrome}

In patients with peripheral arterial disease and concomitant hyperlipidaemia that were treated with sulodexide the following was observed: a decrease in triglyceride and VLDL fraction, and an increase
W trzech badaniach włączonych do metaanalizy chorym podawano 600 LSU sulodeksydu domięśniowo przez pierwsze $20-30 \mathrm{dni}$, a następnie 2 razy dziennie doustnie po 250-500 LSU przez 30-70 dni. W jednym badaniu od początku sulodeksyd podawany był doustnie w dawce 500 LSU na dobę [27].

W badaniu przeprowadzonym przez Bodułę i wsp., w którym oceniano wpływ sulodeksydu i pentoksyfiliny na przebieg miażdżycy zarostowej tętnic obwodowych, potwierdzono korzystny wpływ sulodeksydu na objawy choroby. Stwierdzono istotne wydłużenie dystansu chromania przestankowego oraz redukcję dolegliwości bólowych u chorych leczonych sulodeksydem [28]. Ponadto dystans chromania u chorych stosujących sulodeksyd wydłużył się $\mathrm{w}$ większym stopniu $\mathrm{w}$ porównaniu z chorymi stosującymi pentoksyfilinę. W przeciwieństwie do badania Coccheri i wsp. nie wykazano znamiennego wpływu preparatów na parametry wydolności tętniczej oznaczone w pletyzmografii. U osób z chorobą obwodowych naczyń tętniczych stwierdzono zmniejszenie stężenia trójglicerydów i fibrynogenu, a także wzrost frakcji HDL cholesterolu pod wpływem sulodeksydu [29].

\section{Zespół stopy cukrzycowej}

Zespół stopy cukrzycowej stanowi globalny problem medyczny, społeczny i ekonomiczny [30]. Zespół stopy cukrzycowej występuje nawet u $25 \%$ chorych na cukrzycę [31]. Grupą szczególnie narażoną na rozwój owrzodzeń na tle cukrzycowym oraz amputację kończyn dolnych są pacjenci w podeszłym wieku [32]. Owrzodzenia cukrzycowe rozwijają się przede wszystkim na podłożu neuropatii i chorób naczyń obwodowych [30]. Aby zmniejszyć wskaźniki zachorowalności i umieralności, konieczne jest wczesne rozpoznanie oraz stosowanie profilaktyki zespołu stopy cukrzycowej. Korzystny efekt w leczeniu zaburzeń krążenia obwodowego i regulacji mikrokrążenia rozwijających się na podłożu neuropatii cukrzycowej można osiągnąć za pomocą leków poprawiających właściwości reologiczne krwi, takich jak pentoksyfilina, prostaglandyna E1 i sulodeksyd [33]. Piaggesi i wsp. oceniali skuteczność sulodeksydu jako terapii pomocniczej u chorych z krytycznym niedokrwieniem kończyn w przebiegu cukrzycy, poddanych przezskórnej angioplastyce wewnątrznaczyniowej. U chorych, u których stosowano sulodeksyd, stwierdzono poprawę funkcji mikrokrążenia i redukcję nasilenia bólu, natomiast nie stwierdzono różnic w gojeniu się owrzodzeń i częstości amputacji w porównaniu z grupą kontrolną [34]. Jin i wsp. obserwowali ochronne działanie sulodeksydu w stosunku do uszkodzenia nerwów obwodowych wywołanego dysfunkcją mikronaczyniową u szczurów z wyindukowaną cukrzycą [35]. W badaniu oceniającym stosowanie insuliny w leczeniu stopy cukrzycowej w monote- 
in HDL cholesterol and apolipoprotein A1 with antisclerotic activity. Considering the anti-sclerotic, hypotensive, anti-coagulation, fibrinolytic, anti-inflammatory, fibrosis-inhibiting, and protective for vascular endothelial cells potential, sulodexide may constitute an important part of adjunctive therapy against a spectrum of symptoms that constitute metabolic syndrome [4]. The course of metabolic syndrome includes abdominal obesity, hypertension, dyslipidaemia, and insulin resistance. Thus, sulodexide may be an adjuvant therapeutic option is some dermatological disease entities, such as severe plaque psoriasis, psoriatic arthritis, or hidradenitis suppurativa, which co-exist with metabolic syndrome. Furthermore, treatment of metabolic syndrome may alleviate the course of the underlying disease, and reduce the risk of cardio-vascular complications in these patients $[37,38]$.

\section{Vascular changes in the course of autoimmune connective tissue disorders}

Autoimmune systemic diseases of connective tissue are a heterogeneous group of clinical entities with a complex and not fully known etiopathogenesis. The most common disease entities within this group include systemic lupus erythematosus, systemic sclerosis, dermatomyositis, mixed connective tissue disease, and Sjögren's syndrome. Vascular lesions may be present in even $20 \%$ of patients with systemic connective tissue disease [39, 40]. They are a key part stimulating an immunological cascade leading to tissue inflammation. Existing reports on sulodexide use in autoimmune connective tissue disorders regard only systemic sclerosis; however, considering the presence of vascular disorders in etiopathogenesis of other entities and co-existence of clinical symptoms such as Raynaud's phenomenon, further studies are recommended.

In systemic sclerosis (SSc) important etiopathogenetic factors are disorders in morphology and functions of capillaries [41]. At an early disease stage, changes in architecture and vacuolation of vascular endothelial cells are observed. Damage of the endothelium causes a release of biologically active substances and development of chronic inflammation, intensifies proliferation of vascular smooth muscle cells and fibrosis, which may lead to vascular occlusion and ischaemia [39]. Microcirculation disorders are systemic, affect vessels of the skin, subcutis, muscles, and internal organs. In English publications they are called "vascular disorders" [42, 43].

One of the earlier symptoms of SSc, which may precede other symptoms, is Raynaud's phenomenon (RP) present in more than $95 \%$ of patients. A characteristic triphase colour change within hands and feet is caused by a contraction of arteries responsible for rapii lub z sulodeksydem Koblik i wsp. nie stwierdzili zmian w przewodnictwie nerwowym niezależnie od stosowanej terapii. Potwierdzili natomiast pozytywny wpływ sulodeksydu na mikrokrążenie skórne w zespole stopy cukrzycowej, stwierdzając poprawę reaktywnego przepływu skórnego oraz szybsze gojenie się owrzodzeń [32].

W związku z opisanymi efektami w przebiegu mikroangiopatii cukrzycowej należy wspomnieć o potencjalnym wspomagającym działaniu sulodeksydu w terapii obumierania tłuszczowatego. Znane są doniesienia o skutecznej terapii zmian $\mathrm{w}$ postaci necrosbiosis lipoidica sulodeksydem w dawce dobowej 500 LSU w skojarzeniu z pentoksyfiliną i kwasem hialuronowym. Stwierdzono pozytywny wpływ terapii skojarzonej z sulodeksydem, w wyniku której uzyskano wygojenie $2 / 3$ owrzodzeń i spłycenie $1 / 3$ zmian [36].

\section{Zespół metaboliczny}

U pacjentów z chorobą tętnic obwodowych i współistniejącą hiperlipidemią poddawanych terapii sulodeksydem stwierdzono zmniejszenie stężenia trójglicerydów i frakcji VLDL przy jednoczesnym zwiększeniu stężenia frakcji HDL cholesterolu oraz apolipoproteiny A1 o działaniu przeciwmiażdżycowym. Ze względu na potencjał przeciwmiażdżycowy, a także hipotensyjny, przeciwzakrzepowy, fibrynolityczny, przeciwzapalny, hamujący włóknienie i protekcyjny w stosunku do komórek śródbłonka naczyniowego sulodeksyd jest istotnym elementem terapii wspomagającej skierowanej na objawy składające się na zespół metaboliczny [4]. W przebiegu zespołu metabolicznego stwierdza się otyłość brzuszną, nadciśnienie, dyslipidemię i insulinooporność. Sulodeksyd może być stosowany jako leczenie wspomagające w niektórych dermatologicznych jednostkach chorobowych, takich jak ciężka łuszczyca plackowata, łuszczycowe zapalenie stawów i trądzik odwrócony, które współistnieją z zespołem metabolicznym. Ponadto terapia zespołu metabolicznego może łagodzić przebieg choroby podstawowej oraz redukować ryzyko wystąpienia powikłań naczyniowo-sercowych $[37,38]$.

\section{Zmiany naczyniowe w przebiegu chorób autoimmunologicznych tkanki łącznej}

Autoimmunologiczne choroby układowe tkanki łącznej to heterogenna grupa jednostek klinicznych o złożonej i nie w pełni poznanej etiopatogenezie. Do najczęstszych jednostek chorobowych w tej grupie zalicza się: toczeń rumieniowaty układowy, twardzinę układową, zapalenie skórno-mięśniowe, mieszaną chorobę tkanki łącznej oraz zespół Sjögrena. Zmiany naczyniowe mogą być obecne nawet u $20 \%$ pacjentów z układową chorobą tkanki łącznej $[39,40]$. Stanowią one istotny element pobudzający 
white colour of the skin, then, deoxygenated blood makes the skin blue, and the third phase of active hyperaemia is characterized by erythematous colour. Vascular contraction is caused by physical or emotional stress, cold, mechanical factors, and sometimes without any particular stimulus. Pathogenesis of RP is extremely complex and not fully known. One of the possible factors is disintegration at the level of innervation of capillary wall cells and cell elements of microcirculation [44-46]. There occurs a dysregulation of autonomic nerve fibres, which trigger dilation or constriction of vessels through chemical mediators such as calcitonin gene-related peptide (CGRP), neurokinin $A$, substance $P$, and vasoactive intestinal peptide (VIP). It was shown that patients with RP have a decreased level of vasodilating CGPR in perivascular nerves of finger skin [47], and a decreased level of VIP [48]. Interestingly, the endothelium must be intact in order for vasodilating substances to work normally and lead to a successful dilation of vessels [49]. In case of impaired endothelial integrity, vasodilating effect of substance $P$ is going to be considerably lower [50]. Intracellular pathways, in which cAMP or cGMP decomposed by phosphodiesterase are activated, are responsible for smooth muscle relaxation, and thus, treatment of Raynaud's phenomenon commonly involves phosphodiesterase inhibitors that counter vasoconstriction $[46,51]$. Therefore, it is justified to use sulodexide, which facilitates endothelial integrity and conditions normal activity of vasodilating substances.

Functional and structural disorders in microcirculation leading to changes in vascular tone are important for sulodexide's activity in RP. A significant factor is an increased level of endothelin-1 (ET-1) responsible for constriction of vessels. Interleukin-6 and other pro-inflammatory cytokines [46, 52], whose level is decreased by sulodexide, mediate ET-1 secretion. Endothelial damage leading to modelling of vascular walls and fibrosis, what in turn diminishes lumens of vessels, is critical in development of secondary RP. Sulodexide increases the level of hepatocyte growth factor, and thus, is a potential inhibitor of fibrosis. Moreover, thanks to its above-described antithrombotic and profibrinolytic qualities, it reduces the thromboembolic risk within constricted vessels.

Peripheral vasculopathy and chronic ischaemia in SSc patients lead to development of ulcers and scars within distal phalanges, whereas the progressing necrosis and bone resorption may eventually lead to autoamputation. According to the standpoint of European League Against Rheumatism, first-line treatment for SSc patients with Raynaud phenomenon includes calcium channel blockers such as nifedipine and amlodipine. Another therapeutic option includes phosphodiesterase-5 inhibitors, such as sildenafil, iloprost, and alprostadil. Sulodexide is also listed as an kaskadę immunologiczną, która prowadzi do stanu zapalnego w tkankach. Dotychczasowe doniesienia na temat stosowania sulodeksydu w chorobach autoimmunologicznych tkanki łącznej dotyczą tylko twardziny, a ze względu na udział zaburzeń naczyniowych również w etiopatogenezie pozostałych jednostek oraz współwystępowanie objawów klinicznych, takich jak objaw Raynauda, wskazane są dalsze badania.

W twardzinie układowej (systemic sclerosis - SSc) istotnym czynnikiem etiopatogenetycznym są zaburzenia morfologii i funkcji drobnych naczyń krwionośnych [41]. We wczesnej fazie choroby obserwuje się zmiany architektoniki i wakuolizację komórek śródbłonka naczyniowego. Uszkodzenie śródbłonka powoduje uwolnienie substancji aktywnych biologicznie oraz rozwój przewlekłego stanu zapalnego, wzmaga proliferację komórek mięśniówki gładkiej naczyń i włóknienie, które mogą prowadzić do okluzji naczyń i niedokrwienia [39]. Zaburzenia mikrokrążenia mają charakter ogólnoustrojowy, dotyczą naczyń skóry, tkanki podskórnej, mięśni i narządów wewnętrznych. W piśmiennictwie anglojęzycznym określane są mianem „choroby naczyniowej” [42, 43].

Jednym z najwcześniejszych objawów SSc, który może wyprzedzać inne symptomy, jest objaw Raynauda (Raynaud's phenomenon - RP), obecny u ponad 95\% chorych. Charakterystyczna trójfazowa zmiana kolorów w obrębie rąk i stóp spowodowana jest skurczem naczyń tętniczych odpowiadających za białe zabarwienie skóry, następnie odtlenowana krew nadaje skórze niebieski kolor, a trzecia faza aktywnego przekrwienia charakteryzuje się barwą rumieniową. Skurcz naczyń prowokowany jest stresem fizycznym, emocjonalnym, oziębieniem, czynnikami mechanicznymi, a niekiedy występuje bez jakiegokolwiek bodźca. Patogeneza RP jest bardzo złożona i nie do końca poznana. Jednym z możliwych czynników jest dezintegracja na poziomie unerwienia komórek ścian małych naczyń oraz komórkowych elementów mikrokrążenia [44-46]. Dochodzi do dysregulacji autonomicznych włókien nerwowych, które za pośrednictwem mediatorów chemicznych, takich jak peptyd związany z genem kalcytoniny, neurokinina A, substancja P i wazoaktywny peptyd jelitowy, wyzwalają rozszerzenie lub zwężenie naczyń. U chorych z RP stwierdzono zmniejszone stężenie naczyniorozszerzającego peptydu związanego z genem kalcytoniny (calcitonin gene-related peptide - CGRP) w okołonaczyniowych nerwach skóry palca [47] oraz wazoaktywnego peptydu jelitowego (vasoactive intestinal peptide - VIP) [48]. Do prawidłowego działania substancji naczyniorozszerzających w celu wywołania skutecznego rozszerzenia naczyń śródbłonek musi być nienaruszony [49]. W przypadku zaburzonej integralności śródbłonka efekt naczyniorozszerzający substancji P będzie znacznie zmniejszony [50]. Za relaksację mięśni gładkich odpowiedzialne są wewnątrz- 
alternative and supportive form of treating RP [53]. In SSc patients with secondary microcirculatory disorders and intolerance and contraindication for prostanoids, Walecka et al. used sulodexide administered IV twice a day in the dose of 600 LSU with good therapeutic results. Apart from sporadically observed dizziness and hypotension, no significant side effects were noted. In patients with RP and present erosions as well as ulcers on distal phalanges, a 3-4 day cycle of IV sulodexide in the dose of 600 LSU twice a day every 4-6 weeks improves lesion healing [54].

A glycocalyx layer, which is composed of proteoglycans and glycosaminoglycans connected with them, lines the endothelium from the side of a vascular lumen. In physiological conditions, glycocalyx protects the endothelium from a direct contact with circulating blood components [55]. In vitro studies suggest that supplementing components of the glycocalyx partly repairs damages in the glycocalyx by an increase in synthesis and a decrease in catabolism of glycosaminoglycans $[56,57]$. Sulodexide therapy leads to an increase in precursors for glycosaminoglycan synthesis and allows for reconstruction of damaged glycocalyx, while it simultaneously protects vascular endothelial cells [55]. Progressing vascular damage in SSc results from activation of endothelial cells, apoptosis, and fibrosis of microcirculatory vascular walls. Sulodexide plays a protective role for the endothelium, because it is a building material for its cells - it seals the barrier between circulating blood and vascular wall, as well as reduces permeability of vascular walls, while preventing migration of inflammatory mediators, inhibiting adherence of leucocytes to endothelial walls, and acting as an inhibitor of basic proteins released from leucocytes (including ketapsin G, leucocyte elastase) [1]. Normal structure and function of glycocalyx conditioned by sulodexide guarantees endothelial tightness, which in optimal conditions is able to play its antiplatelet, antithrombotic, and profibrinolytic functions, and stimulated synthesis of nitrogen dioxide [58]. Given the protective influence of sulodexide, it significantly contributes to reconstruction of glycocalyx and improves endothelial function in SSc (fig. 1) [59, 60].

Damage of endothelial cells plays a key role in SSC pathogenesis and results in an increased production of reactive oxygen forms, release of chemokines and growth factors, which lead to recruitment of inflammatory T- and B-cells as well as macrophages, which promote fibrosis. Inflammatory cells, activated as a result of structural damage of vessels, and tissue hypoxia cause further release of reactive oxygen forms, cytokines, and profibrinolytic mediators (including transforming growth factor- $\beta$ (TGF- $\beta$ ), connective tissue growth factor, and insulin-like growth factor) that escalate the disease process. Sulodexide komórkowe szlaki, w których dochodzi do aktywacji cAMP lub cGMP rozkładanych przez fosfodiesterazy, w związku z tym w leczeniu RP powszechnie stosuje się inhibitory fosfodiesterazy przeciwdziałające zwężeniu naczyń $[46,51]$. Uzasadnione wydaje się stosowanie sulodeksydu, który wspomaga integralność śródbłonka i warunkuje prawidłowe działanie substancji naczyniorozszerzających.

Istotnym elementem działania sulodeksydu w przebiegu RP są funkcjonalne oraz strukturalne zaburzenia mikrokrążenia prowadzące do zmiany napięcia naczyń krwionośnych. Ważnym czynnikiem jest zwiększone stężenie endoteliny 1 (ET-1) odpowiadającej za skurcz naczyń. W wydzielaniu ET-1 pośredniczą IL-6 i inne cytokiny prozapalne [46, 52], których poziom zmniejsza sulodeksyd. Krytyczne w rozwoju wtórnego RP jest uszkodzenie śródbłonka prowadzące do przebudowy ściany naczynia i włóknienia, co zmniejsza światło naczyń. Sulodeksyd poprzez zwiększanie poziomu czynnika wzrostu hepatocytów jest potencjalnym inhibitorem włóknienia, a dzięki wymienionym wcześniej właściwościom przeciwzakrzepowym i profibrynolitycznym redukuje ryzyko zakrzepowo-zatorowe w obrębie zwężonych naczyń.

Obwodowa waskulopatia i przewlekłe niedokrwienie u chorych na SSc powodują rozwój owrzodzeń i blizn w obrębie paliczków dystalnych, a postępująca martwica i resorpcja kości mogą prowadzić do autoamputacji. Zgodnie ze stanowiskiem European League Against Reumatism u chorych na SSc z RP leczeniem pierwszego wyboru są antagoniści kanału wapniowego z nifedypiną i amlodypiną. Kolejną opcję terapeutyczną stanowią inhibitory fosfodiesterazy 5, w tym sildenafil, iloprost i alprostadyl. Wśród alternatywnych i wspomagających form terapii RP wymienia się również sulodeksyd [53]. U chorych z zaburzeniami w mikrokrążeniu w przebiegu SSs w przypadku nietoleracji lub przeciwwskazań do terapii prostanoidami Walecka i wsp. stosowali dożylnie sulodeksyd 2 razy dziennie po 600 LSU z dobrym efektem terapeutycznym. Poza sporadycznie obserwowanymi zawrotami głowy i hipotensją nie stwierdzono istotnych objawów ubocznych. U chorych z RP i nadżerkami oraz owrzodzeniami w obrębie paliczków dystalnych 3-4-dniowy cykl terapii dożylnej sulodeksydem w dawce 600 LSU 2 razy dziennie co 4-6 tygodni znacznie poprawia gojenie się zmian [54].

Warstwa glikokaliksu składająca się z proteoglikanów i powiązanych z nimi glikozoaminoglikanów wyścieła śródbłonek od strony światła naczynia. W warunkach fizjologicznych glikokaliks chroni śródbłonek przed bezpośrednim kontaktem z krążącymi elementami krwi [55]. Badania in vitro sugerują, że suplementacja składnikami glikokaliksu częściowo naprawia jego uszkodzenia zarówno poprzez zwiększenie syntezy, jak i zmniejszenie katabolizmu glikozoaminoglikanów 


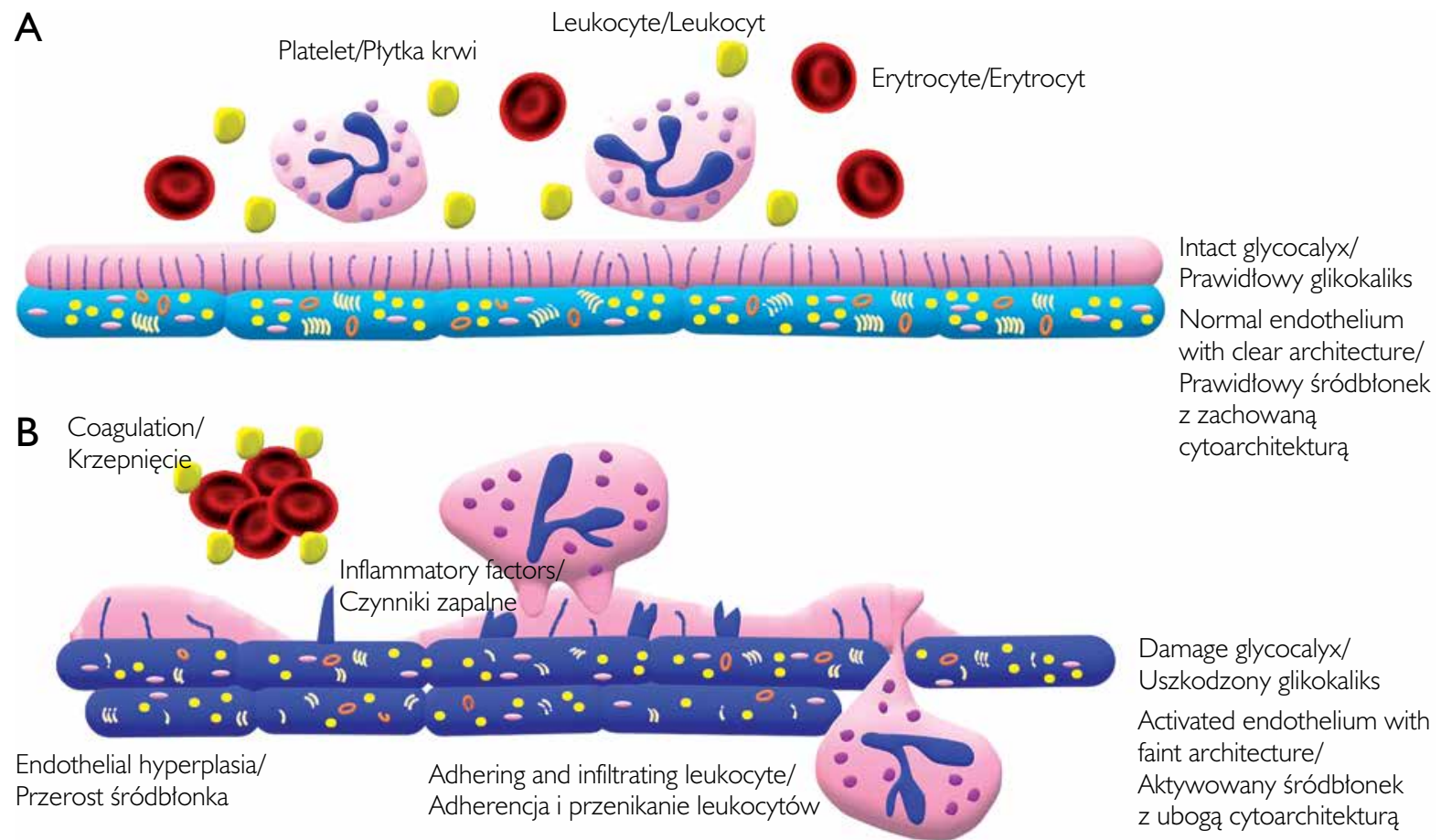

Figure I. The role of glycocalyx in proper endothelial function. A - A normal glycocalyx protects endothelial cells, maintains their proper function and vascular haemostasis. B - Damage of the glycocalyx reveals the underlying endothelium and leads to impaired intravascular haemostasis. This contributes to the proinflammatory endothelial cell phenotype. Activated endothelial cells show increased expression of inflammatory agents, promote adhesion and penetration of inflammatory cells and activate the coagulation process [60]

Rycina I. Znaczenie glikokaliksu dla prawidłowej funkcji śródbłonka. A - Prawidłowa warstwa glikokaliksu chroni komórki śródbłonka, gwarantuje ich prawidłowe funkcjonowanie i zachowanie hemostazy naczyniowej. B - Uszkodzenie glikokaliksu powoduje odsłonięcie znajdującego się poniżej śródbłonka i prowadzi do zaburzenia hemostazy wewnątrznaczyniowej. Przyczynia się to do zmiany fenotypu komórek śródbłonka w prozapalny. Aktywowane komórki śródbłonka wykazują zwiększoną ekspresję czynników zapalnych, indukują adhezję i przenikanie komórek zapalnych oraz aktywują proces krzepnięcia [60]

shows preventive activity in all three stages of SSc pathological process: at the stage when endothelial cells are damaged, during the inflammatory phase, and also during the fibrosis.

Anti-inflammatory qualities of sulodexide that lower concentration of pro-inflammatory cytokines, including IL-1 $\beta$, IL-6, IL-8, MCP-1 and VEGF, may be potentially used in SSc patients $[9,12,13]$. Sulodexide inhibits also metalloproteinases, such as MMP-9, which promote degradation of endothelial cell matrixes $[4,14]$. Sulodexide leads to an increase in hepatocyte growth factor (HGF) concentration, which showed anti-inflammatory activity and played a key role in protection and regeneration of tissue as well as in decreasing susceptibility to chronic inflammation and fibrosis in a study involving tissue-specific knock-out mice targeting the HGF [13]. A participation of HGF/Met pathway in protection and regeneration was shown is various tissues, although it was different depending on its kind. HGF-Met pathway supports protection and regeneration of kidneys, lungs, and nervous, cardio-vascular, cutaneous, as well as gastro-intestinal systems. Apart from promoting cell survival, proliferation, migration, and morphogenesis, its activity includes also inhibition of inflamma-
$[56,57]$. Terapia sulodeksydem prowadzi do wzrostu prekursorów syntezy glikozaminoglikanów, umożliwia odbudowę uszkodzonego glikokaliksu, a także chroni komórki śródbłonka naczyń [55]. Postępujące uszkodzenie naczyń w SSc wynika z aktywacji komórek śródbłonka, apoptozy i włóknienia ścian naczyń mikrokrążenia. Sulodeksyd pełni funkcję ochronną w stosunku do śródbłonka, będąc materiałem budulcowym dla jego komórek - uszczelnia barierę między krążącą krwią a ścianą naczynia i zmniejsza przepuszczalność ścian naczyń, co zapobiega migracji mediatorów zapalenia, hamuje przyleganie leukocytów do ściany śródbłonka, a także jest inhibitorem zasadowych białek uwalnianych z leukocytów (m.in. katepsyny G, elastazy leukocytarnej) [1]. Prawidłowa struktura i funkcja glikokaliksu, którą zapewnia sulodeksyd, gwarantuje szczelność śródbłonka, który w optymalnych warunkach jest zdolny do pełnienia funkcji przeciwpłytkowej, przeciwzakrzepowej, profibrynolitycznej oraz stymuluje syntezę nadtlenku azotu [58]. Ze względu na swój protekcyjny wpływ sulodeksyd przyczynia się istotnie do odbudowy glikokaliksu i poprawy funkcji śródbłonka w przebiegu SSc (fig. 1) [59, 60].

Uszkodzenie komórek śródbłonka odgrywa istotną rolę w patogenezie SSc i skutkuje zwiększoną 
tion and fibrosis. In an experimental model of cirrhosis development in rats, HGF inhibited apoptosis of hepatocytes, and promotes apoptosis of $\alpha$-smooth muscles actin-positive myofibroblast responsible for tissue fibrosis. Studies of Nakamura et al. showed that fibroblasts of patients with idiopathic pulmonary fibrosis have lower abilities to activate HGF precursor as compared with control fibroblasts [61].

Significant clinical problems during the course of systemic sclerosis are digital ulcers and necrosis, which in systemic lupus erythematosus (SLE) patients are observed with antiphospholipid syndrome [62]. Digital ulcers are confirmed in 30\% of SSc patients with limited skin sclerosis, and in $60 \%$ of SSc patients with diffuse skin sclerosis [63]. Ulcer development is aided by lesions confirmed in the course of sclerotic microangiopathy leading to vasocontraction, remodelling of vascular walls, fibrosis, and lumen narrowing, what together with a disorder of coagulation balance and fibrinolysis impairs blood flow and promotes pro-thrombotic conditions, while simultaneously creating ideal environment for development of ulcers and necrotic lesions. Not only does sulodexide play a protective role in function and architecture disorder of vascular endothelium, but it also constitutes a therapeutic option supporting the treatment of skin ulcers in systemic connective tissue diseases thanks to its anti-coagulation activity, enhancing fibrinolytic activity of plasma, decreasing serum viscosity, and anti-sclerotic quality [64]. Furthermore, sulodexide accelerated healing by reducing expression of inflammation-phase markers (including IL-1 $\beta$, IL-12, IL-8, IL-10, GM-CSF, and MMP-9), and increasing expression of granulation-phase markers (including IP-10, PDGFbb, MMP-1, and MMP-7), what in turn leads to faster healing of ulcers [65].

Antiphospholipid syndrome (APS) is an auto-immune acquired coagulation disorder, during which the following is confirmed: presence of auto-antibodies directed against phospholipids of cell membranes or proteins binding phospholipids in patients with symptoms of venous and/or arterial thrombosis or recurring miscarriages [66]. A pathomechanism of APS development has not been fully recognized yet. Potential pathogenetic factors include: inhibition of fibrinolytic system, an increase in prothrombin activity, disorders of anti-coagulation function $\left(\beta_{2}-\right.$ glycoprotein I, proteins $C$ and $S$, or annexin $V$ ), and an increased expression of tissue factor in monocytes and endothelial cells. Furthermore, intensified adhesion and aggregation of blood platelets, increased IL-1 production, and also a potential stimulation of complement system and activation of vascular endothelial cells leading to an increased expression of E-selectin and adhesion molecules (ICAM-1, and VCAM-1) are emphasized. As a result of these reac- produkcją reaktywnych form tlenu, uwalnianiem chemokin i czynników wzrostu, które prowadzą do rekrutacji zapalnych komórek T i B oraz promujących proces włóknienia makrofagów. Aktywowane w wyniku strukturalnego uszkodzenia naczyń komórki zapalne oraz niedotlenienie tkanek powodują dalsze uwalnianie reaktywnych form tlenu, cytokin i mediatorów profibrynogennych, takich jak transformujący czynnik wzrostu $\beta$ (TGF- $\beta$ ), czynnik wzrostu tkanki łącznej i insulinopodobny czynnik wzrostu, które potęgują proces chorobowy. Sulodeksyd ma działanie profilaktyczne obejmujące wszystkie trzy etapy procesu patogenetycznego SSc - uszkodzenie komórek śródbłonka, fazę zapalną i okres włóknienia.

Działanie przeciwzapalne sulodeksydu polegające na zmniejszeniu stężenia cytokin prozapalnych, takich jak IL-1 $\beta$, IL-6, IL-8, MCP-1 oraz VEGF, może być potencjalnie wykorzystane $u$ chorych na SSc $[9,12,13]$. Sulodeksyd hamuje również metaloproteinazy, m.in. MMP-9, które promują degradację macierzy komórek śródbłonka [4, 14]. Pod wpływem sulodeksydu dochodzi do zwiększenia stężenia czynnika wzrostu hepatocytów (hepatocyte growth factor - HGF), który w badaniach z wykorzystaniem specyficznych tkankowo myszy z nokautem w obrębie receptora dla HGF, poza działaniem przeciwzapalnym, odgrywał kluczową rolę $\mathrm{w}$ ochronie i regeneracji tkanki oraz $\mathrm{w}$ zmniejszeniu podatności na przewlekłe zapalenie i włóknienie [13]. Udział szlaku HGF-Met w ochronie i regeneracji wykazano w różnych tkankach, chociaż różnił się on w zależności od jej rodzaju. Szlak HGF-Met wspomaga ochronę i regenerację nerek, płuc, układu nerwowego, sercowo-naczyniowego, skórnego i żołądkowo-jelitowego. Jego działanie, poza promowaniem przeżycia komórek, proliferacji, migracji i morfogenezy, obejmuje również hamowanie stanu zapalnego i włóknienia. W doświadczalnym modelu rozwoju marskości wątroby u szczurów HGF hamował apoptozę hepatocytów oraz promował apoptozę $\alpha$ mięśni gładkich i aktynododatnich miofibroblastów odpowiedzialnych za proces włóknienia tkanki. W badaniach Nakamury i wsp. wykazano, że fibroblasty chorych z idiopatycznym włóknieniem płuc mają mniejszą zdolność do aktywacji prekursora HGF w porównaniu z fibroblastami kontrolnymi [61].

Istotnym problemem klinicznym w przebiegu SSc są owrzodzenia i martwica paliczków dystalnych, które obserwuje się w przebiegu zespołu antyfosfolipidowego $u$ chorych na toczeń rumieniowaty układowy (systemic lupus erythematosus - SLE) [62]. Owrzodzenia paliczków stwierdza się u 30\% chorych na SSc z ograniczonymi stwardnieniami skóry i u 60\% chorych na SSc z uogólnionymi stwardnieniami skóry [63]. Rozwojowi owrzodzeń sprzyjają zmiany stwierdzane w przebiegu mikroangiopatii twardzinowej prowadzące do skurczu naczyń, przebudowy ich ściany, włóknienia 
tions, thrombosis and smooth muscle hypertrophy occur in vessels [67]. Given the pathogenesis, sulodexide supports the treatment of antiphospholipid syndrome. Even though sulodexide does not figure in recommended therapeutic schemes, there are reports regarding its beneficial therapeutic effect as a drug supporting treatment of APS patients or in miscarriages $[67,68]$. Antiphospholipid syndrome secondary to SLE predisposes patients to develop digital ulcers. In such clinical cases, usage of sulodexide may also contribute to an improvement in wound healing and prevention of developing new ones [69].

Rare autoimmune diseases include limited scleroderma with involvement of the skin, subcutis and deeper tissues. Clinical presentation includes an early inflammatory phase, progressing sclerosis, and an atrophic phase. Similarly to SSc, endothelial cell damage is considered to be one of key mechanism in skin lesion development in limited scleroderma. Active foci of limited scleroderma are characterized by erythematous ridge, presence of sclerosis, and extending existing disease foci or appearance of new lesions [70, 71]. In severe forms of progressing limited scleroderma, general treatment involves immunosuppressive and vascular drugs. Pentoxifylline and sulodexide improve vascular flow and protect the endothelium. Oral sulodexide preparations are used in the dose of 500 LSU daily in two divided doses, and IV sulodexide is used in the dose of 600-1,200 LSU daily [72].

\section{Livedoid vasculopathy}

Livedoid vasculopathy (LV) is a rare chronic recurring disease characterized by the presence of livedo racemosa, recurring painful ulcers on lower limbs, and white scars - atrophie blanche [73]. Histopathological presentation includes presence of intravascular thrombosis, endothelial proliferation, and hyaline degeneration within cutaneous vessels. Disease pathogenesis is not fully known. Abnormalities within coagulation and fibrinolysis include: presence of lupus anticoagulant, protein $C$ deficit, increased level of anticardiolipin, cryoglobulinemia, factor V Leiden mutation, mutation of PAI-1 promoter, hyperhomocysteinemia, increased level of lipoprotein A, and anti-thrombin III deficit [74, 75]. Moreover, dysfunction of vascular endothelium, its decreased ability to produce nitrogen monoxide, and tendency for leucocyte adhesion are confirmed. Advantageous response to anticoagulants, and fibrinolytic as well as antiplatelet drugs in some patients supports the theory of LV's thrombotic mechanism [75, 76].

An anti-thrombotic effect of sulodexide, which results from interaction of anti-thrombin III (AT-III) and heparin cofactor II, leads to inhibition of thrombin and prothrombin production, and thus, it delays oraz zwężenia światła, co w zestawieniu z zaburzeniami równowagi procesów krzepnięcia i fibrynolizy upośledza przepływ krwi i promuje stany prozakrzepowe. Są to idealne warunki do rozwoju owrzodzeń i zmian martwiczych. Poza działaniem ochronnym w zakresie zaburzeń funkcji i architektoniki śródbłonka naczyń sulodeksyd dzięki właściwościom antykoagulacyjnym, wzmaganiu fibrynolitycznej aktywności osocza, zmniejszaniu lepkości surowicy oraz działaniu przeciwmiażdżycowemu może być stosowany jako leczenie wspomagające w owrzodzeniach skóry w przebiegu układowych chorób tkanki łącznej [64]. Ponadto sulodeksyd przyspiesza gojenie owrzodzeń, redukując ekspresję markerów fazy zapalnej (m.in. IL-1 $\beta$, IL-12, IL-8, IL-10, GM-CSF, MMP-9) i zwiększając ekspresję markerów fazy ziarninowania (m.in. IP-10, PDGFbb, MMP-1, MMP-7) [65].

Zespół antyfosfolipidowy (antiphospholipid syndrome - APS) jest autoimmunologicznym, nabytym zaburzeniem krzepnięcia, w przebiegu którego stwierdza się obecność autoprzeciwciał skierowanych przeciwko fosfolipidom błon komórkowych lub białkom wiążącym fosfolipidy u pacjentów z objawami zakrzepicy żylnej i/lub tętniczej lub nawracającymi poronieniami [66]. Patomechanizm rozwoju APS nie został dokładnie poznany. Wśród potencjalnych czynników patogenetycznych wymienia się: zahamowanie układu fibrynolitycznego, zwiększenie aktywności protrombiny, zaburzenie funkcji antykoagulacyjnej (m.in. $\beta_{2}$-glikoproteiny I, białka C, S czy anneksyny V) oraz zwiększoną ekspresję czynnika tkankowego na monocytach i komórkach endotelialnych. Ponadto podkreśla się nasiloną adhezję i agregację płytek krwi, zwiększoną produkcję IL-1, a także możliwą rolę pobudzenia układu dopełniacza oraz aktywacji komórek śródbłonka naczyń w zwiększaniu ekspresji E-selektyny i cząsteczek adhezyjnych (m.in. ICAM-1, VCAM-1). Wskutek tych reakcji dochodzi do zakrzepicy i przerostu mięśniówki naczyń [67]. Ze względu na patogenezę zastosowanie sulodeksydu wspomaga terapię APS. Mimo że dotychczas sulodeksyd nie znalazł się $\mathrm{w}$ rekomendowanych schematach terapeutycznych, istnieją doniesienia o jego korzystnym działaniu w terapii wspomagającej u pacjentów z APS lub niepowodzeniami położniczymi [67, 68]. Zespół antyfosfolipidowy w przebiegu SLE predysponuje do tworzenia się owrzodzeń paliczków dystalnych. W takich sytuacjach klinicznych zastosowanie sulodeksydu może się również przyczynić do poprawy gojenia się zmian i zapobiegania powstawaniu nowych [69].

Do rzadkich chorób autoimmunologicznych należy twardzina ograniczona przebiegająca z zajęciem skóry, tkanki podskórnej i tkanek głębiej położonych. Obraz kliniczny choroby obejmuje wczesną fazę zapalną, fazę postępującego stwardnienia i fazę zanikową. Podobnie jak w SSc uszkodzenie komórek śródbłon- 
thrombus formation. Furthermore, sulodexide is an Xa factor inhibitor [1]. LV treatment commonly involves Xa factor inhibitors (rivaroxaban, among others) [77]. Sulodexide exerts anti-coagulation activity, while intensifying fibrinolytic activity of plasma, and prevents blood platelet activation and aggregation, what constitutes a potential benefit for LV patients $[1,9]$.

\section{Oral mucosal ulceration}

Lichen planus (LP) is a chronic inflammatory immune-mediated disease involving skin, oral mucosa, and genital organs, where painful erosions and ulcers may form, thus requiring implementation of immunosuppressive therapies. Due to numerous adverse reactions of systemic therapies, alternative treatment methods are sought. Femiano et al. assessed efficacy of sulodexide as compared with cyclosporine used locally in treatment of erosive lichen of oral mucosa. The authors noted a comparable pain alleviation and erosion as well as ulcer healing in both groups of patients, however, a faster healing process was observed in patients on sulodexide [78]. The same authors assessed efficacy of sulodexide administered orally twice a day in the dose of $250 \mathrm{mg}$ for 40 days in treatment of lichen of the oral mucosa. Histopathological examination performed after the treatment termination revealed subsiding of inflammatory infiltration and lesions within the epithelium. A subsequent evaluation performed after a year from the termination of treatment with sulodexide showed no recurrences in $55 \%$ of patients involved in the study [79].

Recurrent aphthous stomatitis (RAS) is a disease that causes appearance of ulcers within oral mucosa. Clinical presentation of the disease shows presence of minor-type aphthae ( $80 \%$ of cases), major-type aphthae $(10 \%$ of cases) and herpetiform aphthae $(10 \%$ of cases). Clinical management of RAS is determined on the basis of symptom severity, frequency of recurrence, and size as well as number of lesions. Small lesions heal within 7-10 days, extensive lesions may remit spontaneously after about 4-6 weeks [80, 81]. In patients with recurring aphthae resistant to conventional therapies, the authors assessed efficacy of treatment with prednisone used orally in the dose of $25 \mathrm{mg} /$ day during the first week with a subsequent reduction of the dose during 2 months as compared with a sulodexide treatment administered orally in the dose of 250 LSU twice a day during the first month, and the once a day during the second month. No significant differences were observed in pain nullification and lesion remittance in both groups, however, patients using corticosteroids experienced more adverse reactions [81]. Pleiotropic activity of sulodexide allows for using it also in diseases involving ulcers of the oral mucosa. ka uważane jest za jeden z ważnych mechanizmów w rozwoju zmian skórnych w przebiegu twardziny ograniczonej. Aktywne ogniska twardziny ograniczonej cechuje obecność obwódki rumieniowej, występowanie stwardnienia oraz powiększanie się istniejących ognisk chorobowych lub pojawianie się nowych zmian [70, 71]. W ciężkich postaciach twardziny ograniczonej o postępującym przebiegu w leczeniu ogólnym znajdują zastosowanie leki immunosupresyjne i naczyniowe. Pentoksyfilina i sulodeksyd usprawniają przepływ naczyniowy i mają protekcyjne działanie w stosunku do śródbłonka. Preparaty doustne sulodeksydu stosuje się w dawce 500 LSU na dobę w dwóch dawkach podzielonych, a w formie dożylnej 600-1200 LSU na dobę [72].

\section{Livedoid vasculopathy}

Livedoid vasculopathy (LV) jest rzadkim, przewlekłym, nawracającym schorzeniem charakteryzującym się obecnością siności siateczkowatej (livedo racemosa), nawracających bolesnych owrzodzeń na kończynach dolnych oraz białych blizn o charakterze atrophie blanche [73]. W obrazie histopatologicznym stwierdza się obecność zakrzepicy wewnątrznaczyniowej, proliferację śródbłonka i zwyrodnienie szkliste w obrębie naczyń skórnych. Patogeneza choroby nie jest do końca poznana. Wśród nieprawidłowości w zakresie równowagi procesów krzepnięcia i fibrynolizy wymienia się: obecność antykoagulantu toczniowego, niedobór białka C, zwiększone stężenie antykardiolipiny, krioglobulinemię, mutację Leiden czynnika V, mutację promotora inhibitora aktywatora plazminogenu 1, hiperhomocysteinemię, zwiększone stężenie lipoproteiny A i niedobór antytrombiny III [74, 75]. Ponadto stwierdza się zaburzenie funkcjonowania śródbłonka naczyniowego, jego obniżoną zdolność do produkcji podtlenku azotu, a także skłonność do adhezji leukocytów. Korzystna odpowiedź na antykoagulanty, leki fibrynolityczne i przeciwpłytkowe u części pacjentów wspiera teorię zakrzepowego mechanizmu LV [75, 76].

Wynikający z interakcji z antytrombiną III (AT-III) i kofaktorem heparyny II przeciwzakrzepowy efekt stosowania sulodeksydu prowadzi do zahamowania produkcji trombiny oraz protrombiny i opóźnia tworzenie się skrzepu. Ponadto sulodeksyd jest inhibitorem czynnika Xa [1]. W leczeniu LV powszechnie stosowane są inhibitory czynnika Xa (m.in. rywaroksaban) [77]. Działając przeciwzakrzepowo, sulodeksyd wzmaga także fibrynolityczną aktywność osocza oraz zapobiega aktywacji i agregacji płytek krwi, co stanowi potencjalną korzyść dla chorych na LV $[1,9]$.

\section{Owrzodzenia błony śluzowej jamy ustnej}

Liszaj płaski (lichen planus - LP) jest przewlekłą chorobą zapalną mediowaną immunologicznie. Zajmuje skórę i błony śluzowe jamy ustnej i narządów 


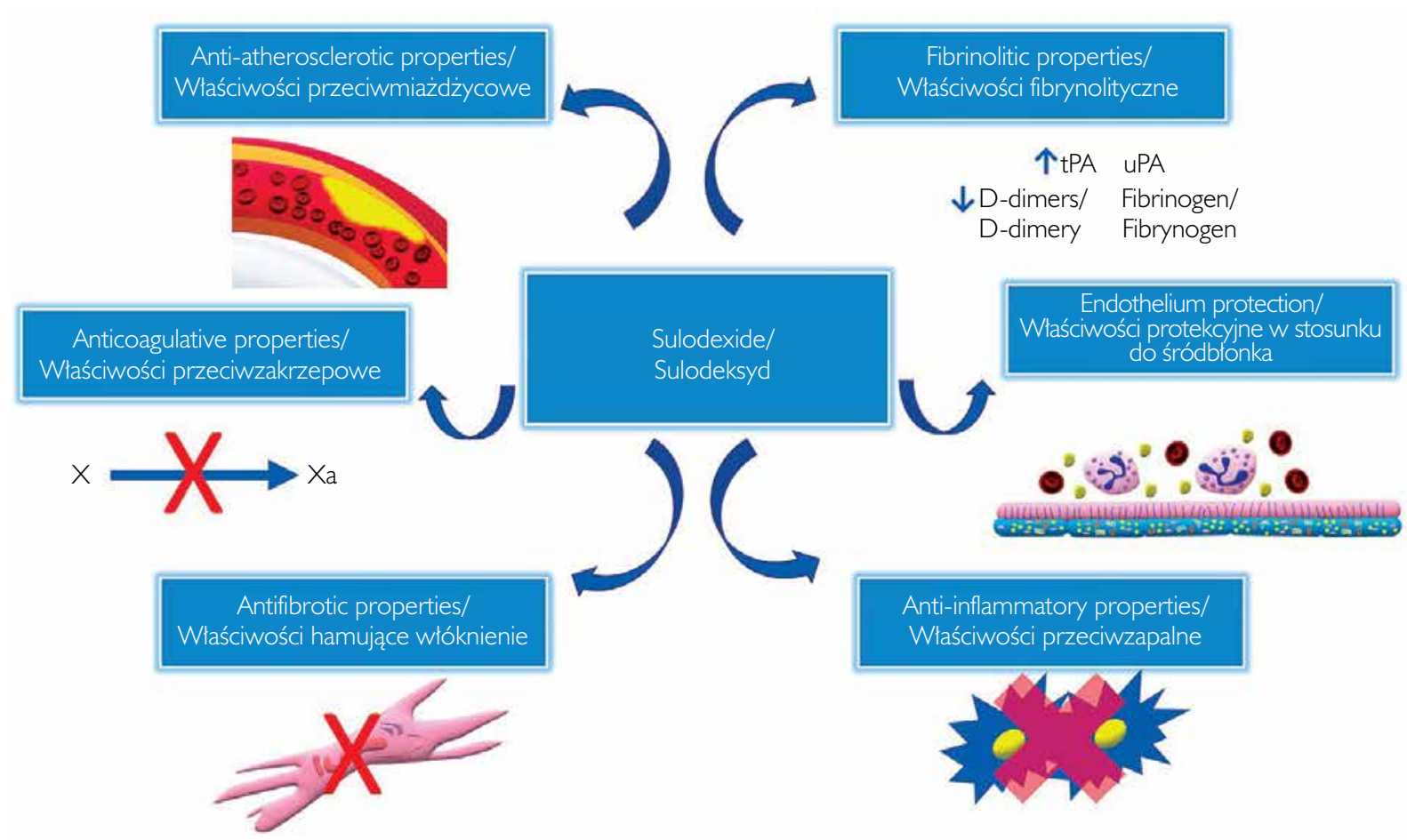

Figure 2. The multiple functions of sulodexide include anticoagulant, profibrinolytic, anti-atherosclerotic, anti-inflammatory, fibrotic and protective effects on vascular endothelial cells

Rycina 2. Wielokierunkowy mechanizm działania sulodeksydu obejmuje właściwości przeciwzakrzepowe, profibrynolityczne, przeciwmiażdżycowe, przeciwzapalne, hamujące włóknienie i protekcyjne w stosunku do komórek śródbłonka naczyniowego

\section{CONCLUSIONS}

Due to a pleiotropic activity and a high safety profile, benefits from using sulodexide may be applied to many dermatological diseases (fig. 2).

Sulodexide is an established drug in prophylaxis and treatment of atherothrombosis, atherosclerosis, chronic venous insufficiency, and lower leg ulcers.

Adjuvant therapy with sulodexide of metabolic syndrome secondary to severe plaque psoriasis, psoriatic arthritis, and hidradenitis suppurativa, may alleviate the course of the underlying disease and decrease the risk of cardio-vascular complications.

The use of sulodexide is beneficial in treatment of livedoid, ischaemic and vascular vasculopathies in systemic connective tissue disorders.

A positive influence of sulodexide was observed in supportive therapies in autoimmune diseases involving a tendency to cause ulcers.

\section{CONFLICT OF INTEREST}

The authors declare no conflict of $\mathrm{i}$ interest. płciowych, w obrębie których mogą się tworzyć bolesne nadżerki i owrzodzenia wymagające terapii immunosupresyjnej. Ze względu na liczne działania niepożądane leczenia ogólnego poszukuje się alternatywnych metod terapii. Femiano i wsp. oceniali skuteczność sulodeksydu w porównaniu z cyklosporyną stosowaną miejscowo w leczeniu nadżerkowego liszaja błon śluzowych jamy ustnej. Stwierdzili porównywalne łagodzenie bólu oraz gojenie się nadżerek i owrzodzeń w obu grupach pacjentów, ale szybszy proces gojenia u pacjentów otrzymujących sulodeksyd [78]. Ci sami autorzy oceniali skuteczność sulodeksydu podawanego doustnie 2 razy dziennie po $250 \mathrm{mg}$ przez $40 \mathrm{dni}$ w terapii liszaja błony śluzowej jamy ustnej. W badaniu histopatologicznym po zakończonym leczeniu wykazano ustąpienie nacieku zapalnego i zmian w obrębie nabłonka. Ponowna ocena po roku od zakończenia terapii sulodeksydem wykazała brak nawrotów u 55\% chorych włączonych do badania [79].

Nawracające aftowe zapalenie jamy ustnej (recurrent aphthous stomatitis - RAS) jest chorobą, która powoduje powstawanie owrzodzeń w obrębie błony śluzowej jamy ustnej. Obraz kliniczny choroby charakteryzuje się obecnością małych aft (80\% przypadków), dużych aft (10\% przypadków) oraz aft opryszczkopodobnych (10\% przypadków). Postępowanie kliniczne w przebiegu RAS ustala się na podstawie nasilenia 
objawów, częstości nawrotów, wielkości i liczby zmian chorobowych. Niewielkie zmiany goją się w czasie 7-10 dni, a zmiany rozległe mogą spontanicznie się cofnać po około 4-6 tygodniach [80,81]. U chorych $\mathrm{z}$ nawrotowymi aftami opornymi na konwencjonalną terapię autorzy oceniali skuteczność prednizonu stosowanego doustnie w dawce $25 \mathrm{mg} /$ dobę przez pierwszy tydzień z następczą redukcją dawki w ciągu 2 miesięcy w porównaniu z sulodeksydem podawanym doustnie $\mathrm{w}$ dawce 250 LSU 2 razy dziennie przez pierwszy miesiąc i raz dziennie w drugim miesiącu. Nie obserwowano istotnych różnic w niwelowaniu bólu i ustępowaniu zmian w obu grupach, ale chorzy stosujący glikokortykosteroidy doświadczyli więcej działań niepożądanych [81]. Plejotropowe działanie sulodeksydu umożliwia jego stosowanie również w chorobach przebiegających z owrzodzeniami w obrębie błony śluzowej jamy ustnej.

\section{WNIOSKI}

Ze względu na działanie plejotropowe i wysoki profil bezpieczeństwa stosowanie sulodeksydu może przynieść korzyści w wielu chorobach dermatologicznych (fig. 2).

Sulodeksyd ma ugruntowaną pozycję w profilaktyce i terapii choroby zakrzepowo-zatorowej, miażdżycy, przewlekłej niewydolności żylnej i owrzodzeń podudzi.

Wspomagająca terapia sulodeksydem zespołu metabolicznego w przebiegu ciężkiej łuszczycy plackowatej, łuszczycowego zapalenia stawów i trądziku odwróconego może łagodzić przebieg choroby podstawowej oraz zmniejszać ryzyko wystąpienia powikłań sercowo-naczyniowych.

Sulodeksyd charakteryzuje się korzystnym działaniem w leczeniu waskulopatii zakrzepowych, niedokrwiennych oraz naczyniowych w układowych chorobach tkanki łącznej.

Stwierdzono pozytywne działanie leku w terapii wspomagającej w chorobach autoimmunologicznych, w których występuje tendencja do tworzenia owrzodzeń.

\section{KONFLIKT INTERESÓW}

Autorzy nie zgłaszają konfliktu interesów.

\section{References}

Piśmiennictwo

1. Harenberg J.: Review of pharmacodynamics, pharmacokinetics, and therapeutic properties of sulodexide. Med Res Rev 1998, $18,1-20$.

2. Bręborowicz A.: Sulodexide - mixture of glycosaminoglycans with the protective effect towards the vascular endothelium. Acta Angiol 2014, 20, 112-118.

3. Lauver D.A., Lucchesi B.R.: Sulodexide: a renewed interest in this glycosaminoglycan. Cardiovasc Drug Rev 2006, $24,214-226$. 
4. Coccheri S., Mannello F.: Development and use of sulodexide in vascular diseases: implications for treatment. Drug Des Devel Ther 2013, 24, 49-65.

5. Veraldi N., Guerrini M., Urso E., Risi G., Bertini S., Bensi D., et al.: Fine structural characterization of sulodexide. J Pharm Biomed Anal 2018, 156, 67-79.

6. Trowbridge J.M., Gallo R.L.: Dermatan sulfate: new functions from an old glycosaminoglycan. Glycobiology 2002, 12, 117R125R.

7. Fransson L.A.: Mammalian glycosaminoglycans. [In:] The Polysaccharides. Vol. 3. G.O. Aspinall (ed.). Academic Press, New York, 1985, 337-415.

8. Milani M.R., Busutti L., Breccia A., Fini A., Piani S., Marchi E.: Pharmacokinetics of sulodexide evaluation from 131-labelled fast-moving heparin after single intravenous and oral administration on man at different doses. Br J Clin Res 1992, 3, 161-178.

9. Połubińska A., Staniszewski R., Baum E., Sumińska-Jasińska K., Bręborowicz A.: Sulodexide modifies intravascular homeostasis what affects function of the endothelium. Adv Med Sci 2013, 58, 304-310.

10. Lauver D.A., Booth E.A., White A.J., Poradosu E., Lucchesi B.R.: Sulodexide attenuates myocardial ischemia/reperfusion injury and the deposition of C-reactive protein in areas of infarction without affecting hemostasis. J Pharmacol Exp Ther 2005, 312, 794-800.

11. Condorelli M., Chiariello M., Dagianti A., Penco M., Dalla Volta S., Pengo V., et al.: IPO-V2: a prospective, multicenter, randomized, comparative clinical investigation of the effects of sulodexide in preventing cardiovascular accidents in the first year after acute myocardial infarction. J Am Coll Cardiol 1994, 23, 27-34.

12. Urbanek T., Zbigniew K., Begier-Krasińska B., Baum E., Bręborowicz A.: Sulodexide suppresses inflammation in patients with chronic venous insufficiency. Int Angiol 2015, 34, 589-596.

13. Borawski J., Dubowski M., Pawlak K., Mysliwiec M.: Sulodexide induces hepatocyte growth factor release in humans. Eur J Pharmacol 2007, 558, 167-171.

14. Mannello F., Ligi D., Canale M., Raffetto J.: Sulodexide down-regulates the release of cytokines, chemokines, and leukocyte colony stimulating factors from human macrophages: role of glycosaminoglycans in inflammatory pathways of chronic venous disease. Curr Vasc Pharmacol 2014, 12, 173-185.

15. Li R., Xing J., Mu X., Wang H., Zhang L., Zhao Y., et al.: Sulodexide therapy for the treatment of diabetic nephropathy, a meta-analysis and literature review. Drug Des Devel Ther 2015, 9, 6275-6283.

16. Satirapoj B., Kaewput W., Supasyndh O., Ruangkanchanasetr P.: Effect of sulodexide on urinary biomarkers of kidney injury in normoalbuminuric type 2 diabetes: a randomized controlled trial. J Diabetes Res 2015, 2015, 172038.

17. Raffetto J.D., Mannello F.: Pathophysiology of chronic venous disease. Int Angiol 2014, 33, $212-221$.

18. Jawień A., Grzela T., Ochwat A.: Prevalence of CVI in Poland. Phlebology 2003, 18, 110-122.

19. Bergan J.J., Pascarella L., Schmid-Schönbein G.W.: Pathogenesis of primary chronic venous disease: insights from animal models of venous hypertension. J Vasc Surg 2008, 47, 183-192.

20. Jarzabek K., Gabryel B., Urbanek T.: Sulodexide in the treatment of vascular disease: its therapeutic action on the endothelium. Phlebol Rev 2016, 24, 51-59.

21. Andreozzi G.M.: Sulodexide in the treatment of chronic venous disease. Am J Cardiovasc Drugs $2012,12,73-81$.

22. Cospite M., Ferrara F., Cospite V., Palazzini E.: Sulodexide and the microcirculatory component in microphlebopathies. Curr Med Res Opin 1992, 13, 56-60.

23. Coccheri S., Scondotto G., Agnelli G., Aloisi D., Palazzini E., Zamboni V.; Venous arm of the SUAVIS (Sulodexide Arterial Venous Italian Study) Group.: Randomised, double blind, multicentre, placebo controlled study of sulodexide in the treatment of venous leg ulcers. Thromb Haemost 2002, 87, 947-952.

24. Coccheri S., Scondotto G., Agnelli G., Palazzini E., Zamboni V.; Arterial Arm of the Suavis (Sulodexide Arterial Venous Italian Study) Group.: Sulodexide in the treatment of intermittent claudication. Results of a randomized, double-blind, multicentre, placebo-controlled study. Eur Heart J 2002, 23, 1057-1065.

25. Kucharzewski M., Franek A., Koziołek H.: Treatment of venous leg ulcers with sulodexide. Phlebologie 2003, 32, 115-120.

26. Zou Y.X., Feng X., Jing Z.P.: Efficacy and safety of sulodexide in the treatment of venous ulcers of leg. Pharm Care Res 2007, 7, 22-24.

27. Wu B., Lu J., Yang M., Xu T.: Sulodexide for treating venous leg ulcers. Cochrane Database Syst Rev 2016, 6, CD010694.

28. Boduła A., Małecki R., Adamiec R.: Comparative evaluation of pentoxyphylline and sulodexide effectiveness in the treatment of symptomatic arteriosclerosis obliterans. Acta Angiol 2010, 16, 18-29.

29. Corsi C., Bocci L., Cipriani C., Gazzini A., Marrapodi E.: The effecitveness of glycosaminoglycans in peripheral vascular disease therapy: a clinical and experimental trial. J Int Med Res 198, 13, 40-47.

30. Sinwar P.D.: The diabetic foot management - recent advance. Int J Surg 2015, 15, 27-30.

31. Alavi A., Sibbald R.G., Mayer D., Goodman L., Botros M., Armstrong D.G., et al.: Diabetic foot ulcers: Part I. Pathophysiology and prevention. J Am Acad Dermatol 2014, 70, 21.e1-18.

32. Koblik T., Sieradzkia J., Sendur R., Biernat J., Czarnobilski K., Gryz E., et al.: The effect of insulin and sulodexide (Vessel Due F) on diabetic foot syndrome. Pilot study in elderly patients. J Diabetes Complications 2001, 15, 69-74.

33. Záhumenský E., Rybka J., Adamíková A.: New aspects of pharmacologic and general prophylactic care of the diabetic foot. Vnitr Lek 1995, 41, 531-534.

34. Piaggesi A., Abbruzzese L., Mattaliano C., Bargellini I., Cicorelli A., Iacopi E., et al.: Sulodexide as adjunctive therapy in diabetic foot patients with critical limb ischemia treated with percutaneous transluminal angioplasty. Int J Low Extrem Wounds 2014, 13, 103-109.

35. Jin H.Y., Lee K.A., Song S.K., Liu W.J., Choi J.H., Song C.H., et al.: Sulodexide prevents peripheral nerve damage in streptozotocin induced diabetic rats. Eur J Pharmacol 2012, 15, 217-226.

36. Pătraşcu V., Giurcă C., Ciurea R.N., Georgescu C.C., Ciurea M.E.: Ulcerated necrobiosis lipoidica to a teenager with diabetes mellitus and obesity. Rom J Morphol Embryol 2014, 55, 171-176. 
37. Lim Z.V., Oon H.H.: Management of hidradenitis suppurativa in patients with metabolic comorbidities. Ann Dermatol 2016, 28, 147-151.

38. Singh S., Young P., Armstrong A.W.: An update on psoriasis and metabolic syndrome: a meta-analysis of observational studies. PLoS One 2017, 12, e0181039.

39. Szymanska E., Wieczorek M., Lagun Z., Malewska A., Roszkiewicz M., Walecka I.: Vascular changes in autoimmunological connective tissue diseases. Acta Angiol 2016, 22, 172-176.

40. Chifflot H., Fautrel B., Sordet C., Chatelus E., Sibilia J.: Incidence and prevalence of systemic sclerosis: a systematic literature review. Semin Arthritis Rheum 2008, 37, 223-235.

41. Krasowska D., Rudnicka L., Dańczak-Pazdrowska A., Chodorowska G., Woźniacka A.: Systemic sclerosis - diagnostic and therapeutic recommendations of the Polish Dermatological Society. Part 1: diagnosis and monitoring. Dermatol Rev 2017, 104, 483-498.

42. Pattanaik D., Brown M., Postlethwaite A.E.: Vascular involvement in systemic sclerosis (scleroderma). J Inflamm Res 2011, 4, 105-125.

43. Michalska-Jakubus M., Krasowska D.: Vascular involvement in systemic sclerosis. Dermatol Rev $2007,94,59-71$.

44. Herrick A.: Raynaud's phenomenon (secondary). BMJ Clin Evid 2014, 2014, 11-25.

45. Herrick A.: Pathogenesis of Raynaud's phenomenon. Rheumatology 2005, 44, 587-596.

46. Prete M., Fatone M.C., Favoino E., Perosa F.: Raynaud's phenomenon: from molecular pathogenesis to therapy. Autoimmun Rev 2014, 13, 655-667.

47. Bunker C.B., Goldsmith P.C., Leslie T.A., Hayes N., Foreman J.C., Dowd P.M.: Calcitonin gene-related peptide, endothelin-1, the cutaneous microvasculature and Raynaud's phenomenon. Br J Dermatol 1996, 134, 399-406.

48. Terenghi G., Bunker C.B., Liu Y.F., Springall D.R., Cowen T., Dowd P.M., et al.: Image analysis quantification of peptide-immunoreactive nerves in the skin of patients with Raynaud's phenomenon and systemic sclerosis. J Pathol 1991, 164, $245-252$.

49. Freedman R.R., Girgis R., Mayes M.D.: Abnormal responses to endothelial agonists in Raynaud's phenomenon and scleroderma. J Rheumatol 2001, 28, 119-121.

50. Smith P.J., Ferro C.J., McQueen D.S., Webb D.J.: Impaired cholinergic dilator response of resistance arteries isolated from patients with Raynaud's disease. Br J Clin Pharmacol 1999, 47, 507-513.

51. Shenoy P., Agarwal V.: Phosphodiesterase inhibitors in the management of autoimmune disease. Autoimmun Rev 2010, 9, 511-515.

52. Rychlik-Golema W., Mastej K., Adamiec R.: The role of endothelin-1 and selected cytokines in the pathogenesis of Raynaud's phenomenon associated with systemic connective tissue diseases. Int Angiol 2006, 25, 221-227.

53. Krasowska D., Rudnicka L., Dańczak-Pazdrowska A., Chodorowska G., Woźniacka A., Lis-Święty A., et al.: Systemic sclerosis - diagnostic and therapeutic recommendations of the Polish Dermatological Society. Part 2: treatment. Dermatol Rev 2017, 104, 583-596.

54. Walecka I., Wislinska P., Kulak A., Roszkiewicz M.: Use of sulodexide for the treatment of disorders of peripheral microcirculation in patients with systemic sclerosis. Acta Angiologica 2017, 23, 139-143.

55. Broekhuizen L.N., Lemkes B.A., Mooij H.L., Meuwese M.C., Verberne H., Holleman F., et al.: Effect of sulodexide on endothelial glycocalyx and vascular permeability in patients with type 2 diabetes mellitus. Diabetologia 2010, 53, 2646-2655.

56. Rossetti L., Hawkins M., Chen W., Gindi J., Barzilai N.: In vivo glucosamine infusion induces insulin resistance in normoglycemic but not in hyperglycemic conscious rats. J Clin Invest 1995, 96, 132-140.

57. Buse M.G.: Hexosamines, insulin resistance, and the complications of diabetes: current status. Am J Physiol Endocrinol Metab 2006, 290, E1-E8.

58. Wasilewski J., Kiljański T., Miszalski-Jamka K.: Role of shear stress and endothelial mechanotransduction in atherogenesis. Kardiol Pol 2011, 69, 717-772.

59. Miranda S., Armengol G., Le Besnerais M., Lévesque H., Benhamou Y.: New insights into systemic sclerosis related microcirculatory dysfunction by assessment of sublingual microcirculation and vascular glycocalyx layer. Results from a preliminary study. Microvasc Res 2015, 99, 72-77.

60. Li T., Liu X., Zhao Z., Ni L., Liu C.: Sulodexide recovers endothelial function through reconstructing glycocalyx in the balloon-injury rat carotid artery model. Oncotarget 2017, 8, 91350-91361.

61. Nakamura T., Sakai K., Nakamura T., Matsumoto K.: Hepatocyte growth factor twenty years on: much more than a growth factor. J Gastroenterol Hepatol 2011, 26, 188-202.

62. Rosato E., Molinaro I., Pisarri S., Salsano F.: Digital ulcers as an initial manifestation of systemic lupus erythematosus. Intern Med 2011, 50, 767-769.

63. Lis-Święty A.: Skin ulcers in systemic sclerosis - etiopathogenesis, prophylaxis and treatment. Dermatol Rev 2018, 105, 509522.

64. Lunetta M., Salanitri T.: Lowering of plasma viscosity by the oral administration of the glycosaminoglycan sulodexide in patients with peripheral vascular disease. J Int Med Res 1992, 20, 45-53.

65. Ligi D., Mosti G., Croce L., Raffetto J.D., Mannello F.: Chronic venous disease - Part II: Proteolytic biomarkers in wound healing. Biochim Biophys Acta 2016, 1862, 1900-1908.

66. Gómez-Puerta J.A., Cervera R.: Diagnosis and classification of the antiphospholipid syndrome. J Autoimmun 2014, 48-49, 20-5.

67. Gerkowicz A., Chodorowska G., Michalak-Stoma A., Juszkiewicz-Borowiec M., Krasowska D., Niewiedzioł M.: Antiphospholipid syndrome - clinical manifestation, diagnostics and literature review. Postep Dermatol Alergol 2010, 27,69-75.

68. Reshetnyak T., Seredavkina N., Satybaldyeva M., Nasonov E., Reshetnyak V.: Liver transplantation in a patient with primary antiphospholipid syndrome and Budd-Chiari syndrome. World J Hepatol 2015, 7, 2229-2236.

69. Shanmugam V.K., Angra D., Rahimi H., McNish S.: Vasculitic and autoimmune wounds. J Vasc Surg Venous Lymphat Disord 2017, 5, 280-292. 
70. Wolska-Gawron K., Krasowska D.: Localized scleroderma - classification and tools used for the evaluation of tissue damage and disease activity/severity. Dermatol Rev 2017, 104, 269-289.

71. Sartori-Valinotti J., Tollefson M., Reed A.: Updates on morphea: role of vascular injury and advances in treatment. Autoimmune Dis 2013, 2013, 467808 .

72. Wolska-Gawron K., Michalska-Jakubus M., Krasowska D.: Localized scleroderma - current treatment options. Dermatol Rev 2017, 104, 606-618.

73. Yong A.A., Tan A.W., Giam Y.C., Tang M.B.: Livedoid vasculopathy and its association with factor V Leiden mutation. Singapore Med J 2012, 53, e258-e260.

74. Vasudevan B., Neema S., Verma R.: Livedoid vasculopathy: a review of pathogenesis and principles of management. Indian J Dermatol Venereol Leprol 2016, 82, 478-488.

75. Alavi A., Hafner J., Dutz J.P., Mayer D., Sibbald R.G., Criado R.P., et al.: Livedoid vasculopathy: an in-depth analysis using a modified Delphi approach. J Am Acad Dermatol 2013, 69, 1033-1042.e1.

76. Criado P.R., Rivitti E.A., Sotto M.N., Valente N.Y., Aoki V., Carvalho J.F., et al.: Livedoid vasculopathy: an intriguing cutaneous disease. An Bras Dermatol 2011, 86, 961-977.

77. Micieli R., Alavi A.: Treatment for livedoid vasculopathy: a systematic review. JAMA Dermatol 2018, 154, 193-202.

78. Femiano F., Gombos F., Scully C.: Oral erosive/ulcerative lichen planus: preliminary findings in an open trial of sulodexide compared with cyclosporine (ciclosporin) therapy. Int J Dermatol 2003, 42, 308-311.

79. Femiano F., Scully C.: Oral lichen planus: clinical and histological evaluation in an open trial using a low molecular weight heparinoid (sulodexide). Int J Dermatol 2006, 45, 986-989.

80. Akintoye S., Greenberg M.: Recurrent aphthous stomatitis. Dent Clin North Am 2014, 58, 281-297.

81. Femiano F., Gombos F., Scully C.: Recurrent aphthous stomatitis unresponsive to topical corticosteroids: a study of the comparative therapeutic effects of systemic prednisone and systemic sulodexide. Int J Dermatol 2003, 42, 394-397.

Received: 27.11 .2018

Accepted: 3.01.2019

Otrzymano: $27.11 .2018 \mathrm{r}$.

Zaakceptowano: $3.01 .2019 \mathrm{r}$.

How to cite this article

Krasowska D., Polkowska-Pruszyńska B., Michalak-Stoma A.: Sulodexide - unrealized potential in dermatology. Dermatol Rev/ Przegl Dermatol 2019, 106, 52-70. DOI: https://doi.org/10.5114/dr.2019.83444. 